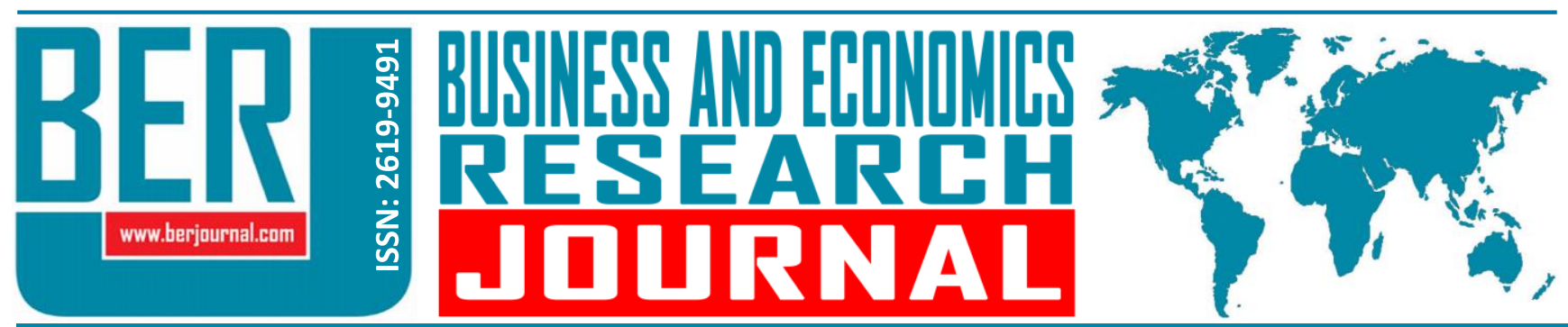

Business and Economics Research Journal Vol. 11, No. 2, 2020, pp. 495-513 doi: 10.20409/berj.2020.263

\title{
Yönetici Desteğinin Çalışanların Kurallara Uyma Davranışı Üzerindeki Etkisi: Havacılık Sektöründe Bir Uygulama ${ }^{1}$
}

\author{
Tugba Gungor Ilerler ${ }^{\mathrm{a}}$, Asena Altin Gulova ${ }^{\mathrm{b}}$
}

Öz: Bu çalışma daha çok sosyal psikologların incelediği bir konu olan sosyal etki ve uyma davranışını, çalışanların iş yaşamındaki kurallara uyma davranışı bağlamında ele almaktadır. Araştırma; (1) havacılık sektörü çalışanlarının algıladıkları yönetici desteğinin çalışanların kurallara uyma davranışı üzerindeki etkisini ortaya koymak, (2) demografik değiş̧enlerin çalışanların kurallara uyma davranışında bir farkılıı yaratıp yaratmadığı ve (3) çalışanların yönetici desteği algılarını belirlemek amacıyla yapılmıştır. Araştırmanın bulguları İmir Adnan Menderes Havalimanı çalışanlarından elde edilen 371 anket üzerinden elde edilmiştir. Çalışmada, Grandey'in $(1999,2000)$ çalışmasının Öz (2007) tarafından Türkçe'ye uyarlaması yapılan Yönetici Desteği Ölçeği ve Kelman'ın (1958) üç uyma davranışı tanımına dayanarak Öz (2007) tarafından geliştirilen Uyma Davranışı ölçekleri kullanılmıştır. Anketlerden elde edilen nicel veriler SPSS ile analiz edilmiştir. Örneklem profiline ilişkin değerlendirmeler yapıldıktan sonra ölçeklerin geçerlilik güvenilirlik analizleri, normallik testleri, faktör analizleri yapılmıştır. Sonrasında araştırmadaki değişkenler arasındaki ilişki düzeyini ve yönünü anlamak için çoklu korelasyon analizi yapılmış ve hipotezleri test etmek üzere t-testleri, ANOVA testleri ve AMOS 22 programı aracılığı ile Yapısal Eşitlik Modeli (YEM) yöntemleri kullanılmıştır. Bulgular; yönetici desteğinin çalışanların kurallara uyma davranışı üzerinde anlamlı etkisini ortaya koymaktadır. Bazı demografik değişkenlere göre de çalışanların yönetici desteği algııı ve kurallara uyma davranışı biçimleri farkılık göstermektedir.

\section{The Effect of Supervisor Support on Employees' Conformity Behaviour to the Organizational Rules: Research in the \\ Aviation Sector}

\begin{abstract}
This study deals with the social impact and conformity behavior, a topic mainly studied by social psychologists, in the context of employees' conformity behavior in the workplace. This research aims to (1) investigate the effect of perceived supervisor support (PSS) of aviation sector employees' on conformity behaviors to the rules, (2) determine whether or not the demographic variables affect the employees' conformity behaviors to the rules and if it creates a significant difference, and (3) determine to employees' perceptions of supervisor support. The results of the study were obtained from 371 surveys from Izmir Adnan Menderes Airport Employees. Two scales were administered to collect data: i) Scale of Supervisor Support developed by Grandey $(1999,2000)$ and adapted to Turkish by Öz in 2007, ii) Scale of Conformity Behaviours developed by Öz (2007) based on Kelman's (1958) definitions of three conformity behaviours. The quantitative data obtained by the questionnaires were analyzed using the SPSS. After analyzing the sample, validity and reliability analyzes, normality test, factor analysis of the scales were carried out. Afterward, multiple correlation analysis was conducted to determine the relationship level and direction of the variable of the research. Moreover, $t$-tests, ANOVA tests, and Structural Equation Model (SEM) methods were used through the AMOS 22 program to test the hypotheses. The results reveal the significant impact of supervisor support on employee conformity behavior. According to some demographic variables, employees' perception of supervisor support and types of conformity to the organizational rules also differs.
\end{abstract}

supervisor support and types of conformity to the organizational rules also differs.

Anahtar Sözcükler: Yönetici Desteği, Uyma Davranışı, Örgütsel Kurallar, Demografik Değişkenler, Havacılık Sektörü

JEL: D23, D73, F55, J11, M12

$\begin{array}{ll}\text { Geliş } & : 26 \text { Eylül } 2019 \\ \text { Düzeltme } & : 17 \text { Ekim } 2019 \\ \text { Kabul } & : 03 \text { Aralık } 2019 \\ & \\ \text { Tür } & : \text { Araştırma }\end{array}$

Keywords: Supervisor Support, Conformity Behaviour, Organizational Rules, Demographic Variables, Aviation Sector

JEL: D23, D73, F55, J11, M12

Received : 26 September 2019 Revised : 17 October 2019

Accepted : 03 December 2019

Type : Research

Cite this article as: Gungor-Ilerler, T., \& Altin-Gulova, A. (2020). Yönetici desteğinin çalışanların kurallara uyma davranışı üzerindeki etkisi: Havacılık sektöründe bir uygulama. Business and Economics Research Journal, 11(2), 495-513.

The current issue and archive of this Journal is available at: www.berjournal.com

a PhD., General Directorate of State Airports Authority, Adnan Menderes Airport, Izmir, Turkiye, tugbagungor@gmail.com (ORCID ID: 0000-0002-5904-7853)

b Assoc. Prof., PhD., Manisa Celal Bayar University, Faculty of Economics and Administrative Sciences, Department of Business Administration, Manisa, Turkiye, asena.gulova@cbu.edu.tr (ORCID ID: 0000-0003-2914-0632) 


\section{Giriş}

Sosyal hayatta yaşamın getirdiği bazı sosyal kurallar olduğu gibi örgütlerde de bir takım işyeri kuralları vardır. Bu kurallar iş yaşamında kişilerin birbirleri ile olan ilişkilerinde, yaptıkları işler ile ilgili veya örgütün dış çevre ile ilgili işlerinde uymak zorunda olduğu kurallardır. İş yaşamında birey-birey, birey- örgüt uyumunun sağlanmasında önemli paya sahip olan örgütsel kurallar; klasik, neo-klasik veya modern tüm örgüt kuramlarında politikalar, prosedürler, süreçler, izlenecek yollar başlı̆ı̆ altında incelenmiştir. Örneğin; Taylor (1911) yazmış olduğu "Bilimsel Yönetim Ilkeleri" eserinde en iyi yönetimin iyi tanımlanmış kanunlara, kurallara, ilkelere dayalı olduğundan bahsederek (Yüksel ve Aykaç, 1994: 83-84), bilimsel yönetime teknik açıdan yaklaşan Fayol (1916) ise işletme faaliyetlerinin faaliyetlerin yürütülmesinde bir takım ilke ve kaidelere uyulması gerektiğini açıklayarak (Özalp, 1992: 75-97) örgütsel kuralların varlığına ve önemine dikkat çekmişlerdir.

Bir örgütte çalışanın birebir temas halinde olduğu kişi örgütün kendisi değil bir üst amiridir (Eisenberger, Stinglhamber, Vandenberghe, Sucharski ve Rhoades, 2002.) Çalışanların kurallara uymasında yönetici desteğinin bir güven aracı olarak önemli bir rol oynayacağı düşünülmektedir. Yöneticisine güvenen, ona saygı duyan ve onun iyi niyetini fark eden bir işgören onun yaklaşım tarzıyla örgütün koyduğu kuralların anlamlılığına inanacak ve bir yöneticinin, kuralı anlayış ve uygulayış biçimi çalışanın o kurala uyma biçimini etkileyeceği düşünülmektedir.

Literatürde; örgütsel işleyişin düzgün sağlanabilmesi için örgütsel kuralların gerekliliği ve bu kurallara uymanın önemine vurgu yapan birçok sözel yargı bulunmasına karşın çalışanların iş yaşamında örgüt kurallarına uyma biçimi sorunu hiç tartışılmamıştır. Aynı zamanda yönetici desteğinin birçok değişken üzerinde pozitif etkileri olduğunu belirleyen çalışmalar olmasına rağmen yönetici desteği ve çalışanların kurallara uyma davranışı arasındaki potansiyel ilişkiyi inceleyen bir çalışma bulunmamaktadır.

Bu çalışmanın amacı; dünya ekonomisinde önemli bir paya sahip, sürekli gelişen, dinamik, teknoloji ve rekabet yoğun, nitelikli personel istihdamını gerekli kılan bunun yanında en önemli dezavantajı risk yoğun olan ve kurallara uymanın hayati önem taşıdığı havacılık sektöründe çalışanların yönetici desteği algısını belirlemek, algılanan yönetici desteğinin ve demografik değişkenlerin çalışanların kurallara uyma biçimini etkileyip etkilemediğini ortaya koymaktır.

\section{Literatür İncelenmesi}

Bu bölümde, çalışmanın değişkenleri olan yönetici desteği ve kurallara uyma davranışı hakkında literatür incelemesi yapılmış olup araştırmanın kuramsal çerçevesi hakkında bilgi verilmiştir.

\subsection{Yönetici Desteği}

Örgütsel desteğin önemli bir bileşeni (Kottke ve Sharafınski, 1988) olan yönetici desteği literatürde genel olarak amiri tarafından çalışanın mutluluğunun önemsenmesi ve çalışanın örgüte yönelik katkılarına değer verilme derecesi olarak ifade edilmiştir. Diğer bir ifadeyle çalışanların örgüte kattığı anlamın yönetici tarafından değer görüp görmediği yönünde çalışan algısı olarak da açıklanabilir (Eisenberger, Huntington, Hutchison ve Sowa, 1986; Kottke ve Sharafinski, 1988; Eisenberger vd., 2002; Maertz, Griffeth, Campbell ve Allen, 2007; Newman, Thanacoody ve Hui, 2011).

Çalışanın bağlı bulunduğu yöneticisi, çalışan hakkındaki olumlu değerlendirmeleri ve kayıtları örgüte kolayca aktarabilen, çalışanların performansını değerlendiren yönetme sorumluluğu verilmiş örgütün temsilcileri olarak görev yaparlar (Eisenberger vd., 2002: 565-572). Çalışmasında sosyal bir destek türü olarak yönetici desteğinin önemine vurgu yapan Yoon ve Lim (1999: 925) yönetici desteğini; örgütte odak noktası olan çalışanın en yakınında olan yöneticisi tarafından verilen destek olarak adlandırmıştır.

Tongur'a (2011) göre çalışanların yönetici değerlendirmelerine göre iş ortamında davranışlarını geliştirmelerinin iki nedeni vardır. Birinci neden, çalışan bakış açısıyla örgütü asıl temsil edenin yönetici olmasıdır. İkinci neden ise yöneticilerin çalışan şartlarını, davranışlarını ve katkılarını değerlendirici otorite konumunda olmasından kaynaklanmaktadır. Bu nedenle yöneticiden gelen destek örgütten gelen destek 
anlamına gelmektedir (Yaşar vd., 2014: 44). Kısaca, çalışanların işletme içinde birer sosyal varlık olarak görülmesi, önemsenmesi, başarıları ile övünülmesi ve takdir edilmesi konusunda gerekli hassasiyeti gösteren yöneticiler destekleyici yönetici olarak algılanırlar (Özdevecioğlu, 2003: 118). Yüksek destek algısı hisseden çalışanlar örgütlerine güçlü duygular besler ve daha sadakatli olurlar (Eisenberger, Fasolo ve Lamastro, 1990: 57).

\subsection{Uyma Davranışı}

Sosyal psikolojide Asch'in çalışmalarıyla gündeme gelen uyma (conformity) kavramı, "bireyin kendi düşünce ve davranışını çeşitli nedenlerle değiştirerek kendisinden farklı gördüğü grup normu doğrultusunda görüş bildirmesi veya davranması" olarak tanımlanabilir (Hortaçsu, 2012: 477). Sosyal etkinin karmaşık bir biçimi olan uyma davranışının özündeki gerçek, kişinin davranışlarını başkalarının gerçek ve hayali etkisi sonucu değiştirmesidir (Aronson, Wilson ve Akert, 2012: 423). Kısaca, bir kişinin başkaları öyle davrandığı için bir davranışta bulunmasına uyma davranışı denilmektedir (Freedman, Sears ve Carlsmith, 2003: 454).

Kağıtçıbaşı (2013) çalışmasında uyma davranışının toplumsal yaşam için zorunlu olduğunu, toplumsal düzenin sağlanması için bir takım kuralların oluşturulduğundan ve bu kurallara bazen zorunlu olarak bazen isteyerek bazen de başkalarının davranışına güvenip onların davranışının gerçeği yansıttığına inanılmasından dolayı uyulduğunu ifade etmiştir. Elbette uyma davranışı bireyin başka bir bireye uyması ya da bireyin bir gruba uyması şeklinde olabilmektedir.

Bu çalışmada uyma davranışı, ilk kez Kelman (1958) tarafından ayırt edildiği şekliyle ve Kağıçıbaşı'nın (2013) bakış açısıyla ele alınmıştır. Kelman (1958) tarafından sosyal etki ve tutum değişimi süreçleri olarak geliştirilen benimseme (internalization), özdeşleşme (identification) ve itaat (compliance) kavramları, Kağıtçıbaşı $(1988,2010,2013)$ tarafından uyma davranışının nedenleri olarak görülmüş ve uyma davranışının türleri olarak kategorileştirilmiştir.

Kelman'a (1958) göre bu üç uyma davranışı belli koşullarda meydana gelmektedir. Teşvik edilen davranışın içeriği özünde faydalı (rewarding) olduğunda benimseme; bir bireyin başka bir kişi veya grup ile kendini tanımlayan memnuniyet verici bir ilişki kurulduğunda özdeşleşme, o kişi veya gruptan olumlu tepki almayı umması durumunda itaat şeklinde görülen davranış biçimleri meydana gelmektedir.

Kelman'a göre (1958) kişinin değerler sistemi ile uyumlu olduğunda ortaya çıkan teşvik edilen davranış edimine benimseme davranışı denmektedir. Kişi teşvik edilen davranış ediminin bir problemin çözümü için faydalı olacağını düşünebilir ya da ihtiyaçlarına uygun bulabilir. Edinilen davranış ile kişinin var olan değerleri arasında bütünleşik bir ilişki vardır. Benimsemeden elde edilen memnuniyet yeni davranışın içeriğinden kaynaklanmaktadır. Kağıtçıbaşı (2013: 101), benimseme türü uyma davranışında kişinin, bir kurala ya da görüşe onun doğruluğuna inandığı için uyduğunu, burada uyulanın fikri, uyan kişi için inanılan doğru bir fikir olduğu için kabul ettiğini ifade etmiştir.

Kelman'a (1958) göre bireyin başka bir kişi ile ya da bir grup ile kurduğu ilişki, bireyin diğerinin rolünü üstlendiği klasik özdeşleşme biçimini alabilir veya karşılıklı rol ilişkisi biçiminde olabilir. Birey gerçekte özdeşleşme yoluyla edindiği yanıtlara inanır fakat onların içeriği az-çok alakasızdır. Teşvik edilmiş davranış, arzu edilen ilişkiyle alakalı olduğu için edinilir. Özdeşleşmeden elde edilen memnuniyet uyum sağlama hareketinden kaynaklanmaktadır. Kağıtçıbaşı (2013: 100), özdeşleşme türü uyma davranışında kişinin, başka bir kişinin ya da grubun fikrine, ona benzeyebilmek için uyduğunu bu davranışın temelinde uyulanın cazibesi ve değeri olduğunu belirtmiştir.

Kelman'a göre (1958), teşvik edilen davranışın içeriğine inanıldığı için değil de belirli ödülleri veya onayları almak ve belirli cezalardan, onaylanmama durumundan kaçınmak amacıyla ortaya çıkan davranış türüne itaat denmektedir. İtaatten elde edilen memnuniyet sosyal bir etkiden kaynaklanmaktadır. Kağıtçıbaşı (2013: 100), itaatin bir kişiye uyma ya da bir grubun görüşüne uyma şeklinde olduğunu ve bu davranışın temelinde uyulanın gücü ve kontrolü olduğundan bahseder. 


\subsection{Yönetici Desteği ve Kurallara Uyma Davranışı Arasındaki Iilişki}

Yönetici desteği ve çalışanların kurallara uyma davranışı arasındaki ilişkinin öncülü olarak yönetici desteğinin çeşitli örgütsel çıktılar arasında ilişkilerini görmek mümkündür. Literatürde yönetici desteğinin; örgütsel adalet (Yaşar vd., 2014; Aksoy, 2017), örgütsel bağlılık (Singh, 2000; Yaşar vd., 2014; Emhan, 2012; Emhan, Kula ve Tongur, 2013; Kopp, 2013), iş tatmini (Emhan, 2012; Kopp, 2013), iş-yaşam dengesi (Kopp, 2013), iş-aile yaşam çatışması (Kossek, Pıchler, Bodner ve Hammer vd., 2011; Çelik ve Turunç, 2010), örgütsel vatandaşlık davranışı (Kopp, 2013; Özdemir, 2010), iş tutumu (Gagnon ve Michael, 2004; Ackfeldt ve Coote, 2005), iş performansı (Rhoades ve Eisenberger, 2002; Gagnon ve Michael, 2004; Çelik ve Turunç, 2010; Dilek ve Bilgin, 2012), örgütsel özdeşleşme (Dilek ve Bilgin, 2012; Uzun, 2018) gibi birçok örgütsel çıktı üzerinde pozitif bir ilişkisi olduğu tespit edilmiştir. Yönetici desteği aynı zamanda çalışanların işe bağlığını arttırıp işten ayrılma niyetini azaltmaktadır (Öz, 2007). Bununla birlikte Gülova vd.'nin (2013) çalışmasında yönetici desteğinin derinlemesine ve samimi davranışı pozitif yönde etkilediği tespit edilmiştir. Demirbağ vd. (2013) yaptıkları çalışmada ise çalışanların kariyer basamaklarında yükselirken algılanan yönetici desteğinin geribildirim arayışına etkisinde öz yeterliliğin düzenleyici etkisi olduğunu bulmuşlardır. Emhan vd.'nin (2013) çalışmasında yönetici desteğinin örgütsel bağııı̆̆ı artırdığı, örgütsel bağlılı̆̆ın örgütsel performansa katkı sağladığı ve böylece çalışanların tükenmişlik düzeylerinde önemli etkileri olduğu görülmüştür.

Uyma davranışı türleri (benimseme, özdeşleşme ve itaat) ise literatürde farklı yönlerden ele alınmıştır. Ulusal literatürde; benimseme üzerine çalışmalar daha çok yeniliklerin benimsenmesi (Usluel, Avcı, Kurtoğlu ve Uslu, 2013), örgütsel değerlerin benimsenmesi (Tak ve Çifçioğlu, 2008; Demirel, 2008), Teknoloji Kabul Modelini (TAM) temel alarak bireylerin internet bankacılığını benimsemesi (Usta ve Eyüpoğlu, 2010; Şıkel, 2011) ve etkileyici iletişim kaynağının benimsenmesi (Usta ve Eyüpoğlu, 2010) gibi konular üzerine yoğunlaşmıştır.

Literatürde, benimseme kavramı Kelman'ın (1958) benimsemesi gibi "kişinin değerler sistemi ile uyumlu olduğunda ortaya çıkan teşvik edilen davranış edimi" anlamını kısmen taşısa da zaman zaman İngilizce "adaptation" ya da acceptance" karşılığında kullanılarak yeni bir duruma, yeni bir teknolojiye uyum gösterme ya da o yenilikleri, durumları kabul etme şeklinde yorumlanmıştır. Bazen de benimseme ve özdeşleşme kavramlarının birbirlerinin içine geçen ifadeler olarak kullanıldığı görülmüştür. Demirel (2008) ve Şıkel'in (2011) çalışmaları bu ifade tarzına örnek gösterilebilir. Örgüte ve yöneticiye duyulan güvenin, duygusal, devamlılık ve normatif bağlılık üzerindeki etkisini inceleyen Demirel (2008) çalışmasında, kişilerin kendi değerlerini örgüte ve yöneticiye duyulan güven sayesinde kendiliğinden örgüte aktararak örgütsel değerleri benimseyeceğini, bu değerler ile özdeşleşeceğini belirtmiştir. Şıkel'in (2011) ise Teknoloji Kabul Modelini (TAM) temel alarak internet bankacılığının benimsenmesi üzerine yaptığı çalışmasında "internet bankacılığını kullanacağım zaman başkalarının tavsiyelerini dikkate alırım, internet bankacılığını kullanan kişiler prestij sahibidir, davranışlarında örnek aldığım kişiler internet bankacılığını kullanırlar, benim için önemli olan kişilerin internet bankacılığını kullanması gerektiğini düşünüyorum" gibi önermeler bulunmaktadır. Konu internet bankacılı̆ıının benimsenmesi olarak geçse de önermeler Kelman'ın (1958) kısmen özdeşleşme türüne uymaktadır.

Özdeşleşme ile ilgili literatür incelendiğinde ulusal ve uluslararası literatürde özdeşleşmenin örgütsel boyutunun daha çok "örgütsel özdeşleşme" şekliyle irdelendiği görülmüştür. Ulusal literatürde ise örgütsel özdeşleşmenin sosyal kimlik teorisi kapsamında incelendiği (Tak ve Çiftçioğlu, 2009) çalışmaların yanı sıra örgütsel özdeşleşme ile örgütsel adalet ve işten ayrılma niyeti (Turunç, 2011), bireylerin sinik tutumları ve işten ayrılma niyeti (Polat ve Meydan, 2010), örgütsel sosyalleşme ve örgütsel vatandaşlık davranışı (Balcı, Baltacı, Fidan, Cereci ve Acar, 2012) arasındaki ilişkileri inceleyen, örgütsel özdeşleşmeyi güçlendiren bir unsur olarak örgütsel iletişim örüntüsüne dikkat çeken (Tüzün ve Çağlar, 2008), örgütsel özdeşleşmenin örgütsel güven ile örgütsel vatandaşlık davranışı arasındaki ilişkiye aracılık etkisi yapacağını ileri süren (Tokgöz ve Seymen, 2013), örgütsel özdeşleşme ve örgütsel bağılıı̆ı algılanan yönetici davranışları açısından inceleyen (Erdoğdu ve Aydındağ, 2013), bireylerin bir grupla ile özdeşleşmesinde bireylerin davranışlarına etkisinin araştııılığı ve özdeşleşmeyi etkilemesi olası faktörlerin (memnuniyet, katıım, prestij ve paylaşılan değerler) ortaya çıkartıImasını amaçlayan (Ceylan ve Özbal, 2008) çalışmalar örgütsel özdeşleşme alanında yapılan çalışmaların bazılarıdır. 
Literatürde itaat/boyun eğme ile ilgili çalışmalar incelendiğinde ise "itaat" kavramının farklı konular içerisinde değerlendirildiği dikkat çekmiştir. Üniversite öğrencilerinde boyun eğici davranışları etkileyen faktörlerin neler olduğunu belirlemeyi amaçlayan (Koç, Bayraktar ve Çolak, 2010), çocukluğunda kendisine yönelik veya aile içi şiddete tanıklık etme durumunun kişilerde boyun eğici ve çekingen tutumların gelişmesini kolaylaştırabileceğini savunan (Kaya, Güneş, Kaya ve Pehlivan, 2004), Akgündüz'ün (2014) çalışmasında olduğu gibi boyun eğme davranışını işgören sessizliği kapsamında değerlendiren, işgörenlerin örgütsel sessizlik yaşama sebepleri olarak en büyük etkenin yaşadıkları korku ve kaygıları olduğunu belirten, çalışan itaatini işgörenlerin örgütte sessizliklerini ifade etmenin bir biçimi olarak gören, Kılıçlar ve Harbalıŏlu (2014), itaati bir girişimcilik değeri olarak görüp itaat ile örgütsel vatandaşlık davranışı boyutları (örgütsel gelişime katkı, sahiplenme, işe özen gösterme, centilmenlik) arasındaki ilişkiyi ölçen (Yener ve Akyol, 2009) çalışmalar yer almaktadır.

Literatürde yöneticilerin çalışanların kurallara uymasında önemli etkiye sahip kişiler olduğunu vurgulayan çalışmalardan Warren G.Bennis $(1969,1970)$ çalışmalarında keyfi koyulan kuralların sakıncalarına dikkat çekmiş, bürokratik örgütlerin başına teknik yetenekten yoksun yöneticilerin geçebileceğini, rasyonel olmayan gülünç kuralların uygulanabileceğini ve yöneticilerin astlarına insan onuruna yakışmayan veya rasyonellikten uzak subjektif uygulamalarda bulunabileceklerinden bahsetmiştir (Şimşek, 2005: 55-56). Vries ve Miller (1984) üst yönetimin nevrotik stillerinin örgütsel bozuklukların önemli belirleyicileri olduğuna dikkat çekerek kurallara uyma konusunda üst yöneticilerin büyük etkisinin olduğunu ifade etmiştir. Rahim (1989) ise çalışmasında astların uzmanlık ve karizmatik gücünü kullanan yöneticilerden daha fazla tatmin olduklarını ve onların isteklerine daha fazla uyma eğilimi içinde olduklarını tespit etmiştir (Erkuş, 2011: 136). Muse ve Pichler (2011) ise yöneticileri örgütün kurallarını ve prosedürlerini yerine getirmekten sorumlu temsili güç olarak tanımlamıştır (Göktepe, 2016: 26). Robbins (1996), iş yaşamında işveren ile çalışanlar arasında psikolojik sözleşme imzaladıklarını belirterek çalışanların isteğinin iyi çalışma koşulları, görev tanımlarının belirlenmiş olmasına karşılık kendilerinden beklenin ise kurallara uyulması ve bağlılık göstermesi (Demirkasımoğlu, 2012: 4) olduğunu vurgulamıştır.

O'Reilly ve Chatman (1986) çalışmasında; örgüt içi bir takım örgütsel rollerin örgütsel bağıılığın psikolojik yönü ile bağlantısını, Kelman'ın (1958) üç uyma davranışı arasındaki ilişkiyle açıklamaya çalışmışır. İki yazar; benimseme ve özdeşleşme davranışlarının kişilerin örgüt adına zaman, çaba ve para harcama istekleri ile güçlü bir ilişkisi olduğuna dikkat çekmişlerdir.

Ulusal literatürde; Kelman'ın (1958) üç sürecini konu alarak yapılan çalışmalar oldukça sınırlıdır. Şimşek'in (2002) çalışması pazarlama dalında yapılacak çalışmalara ve Öz'ün (2007) çalışması yönetim dalında yapılacak çalışmalara örnek olabilir. Şimşek'in (2002) ve Öz'ün (2007) çalışmaları şöyle özetlenebilir: Bir kitle iletişim aracı olarak etkin bir reklam geliştirmek için iletişim ve iletişim sistemleri hakkında bilgi veren Şimşek (2002) çalışmasında etkileyici iletişim açısından kaynağın özelliklerinin Kelman'ın üç süreç (benimseme, özdeşleşme, itaat) kuramına göre açıklanabileceğini anlatmıştır. Öz (2007) çalışmasında duygusal davranış kuralları ile duygusal emek davranışları ilişkisinde uyma davranışının üç türünün şartlı değişken olarak rolünü hiyerarşik regresyon analizi ile incelemiştir. Analiz sonucunda davranış kurallarından ve uyma davranışlarından sadece itaat ve özdeşleşmenin üç duygusal emek davranışı (rol yapma, gerçek duyguları gizleme ve derinlemesine davranma) üzerinde bir etkisi olduğu, özdeşleşmenin ise şartlı bir değişken olarak hiçbir rolü olmadığı görülmüştür.

Örgütsel birçok çıktı üzerinde olumlu etkisi bulunan Yönetici desteğinin, çalışanların kurallara uyma davranışı üzerinde de potansiyel bir etkisi olacağı varsayılmıştır Literatürde, örgütsel düzenin sağlanmasında örgütsel kuralların gerekliliği, kuralların işgörenler tarafından örgüt içinde etkin bir biçimde uygulanabilmesi ve verimli bir geribildirim sağlanabilmesinin temel anahtarı yönetici desteği olarak görülmüştür. Bazı çalışanlar yönetici desteği olsun olmasın koyulan kuralları kabul ederek onları benimseyip, bazıları ise yöneticisini örnek alıp, ona benzemek isteyerek ya da kurallara uyulmadığında çeşitli yaptırımlardan çekinildiği için kurallara itaat yoluyla uyma yolunu seçebilir. 


\section{Etkisi}

2.4. Çalışanların Yönetici Desteği Algısı ve Kurallara Uyma Davranışında Demografik Değişkenlerin

Yönetici desteği ve demografik değişkenlerin ilişkileri üzerine yapılan çalışmalarda demografik değişkenlerden; eğitim (Karatepe ve Kılıç, 2007), cinsiyet ve unvan (Emhan vd., 2013), iş tecrübesi (Emhan vd., 2014), çalışılan birim, eğitim durumu ve çalışma periyodu (vardiyalı/vardiyasız) (Ceylan, Çelik ve Emhan, 2015), iş tecrübesi ve unvan (Arslan, 2019) değişkenlerinin yönetici desteği üzerindeki etkisi istatistiksel olarak anlamlı bulunmuştur. Havacılık sektöründe yapılan bir çalışmada çalışanların yönetici desteği algısı ile demografik değişkenlerden yaş değişkeni arasında istatistiksel olarak anlamlı bir fark olduğu tespit edilmiştir (Aksoy, 2017). Aksoy'un (2017) çalışmasına göre çalışanların yönetici desteği algı ortalamalarının en yüksek olduğu yaş aralı̆̆ı 50 yaş ve üzeri olarak çıkmıştır.

Literatürde uyma davranışı ile ilgili çalışmalar ise ilk olarak demografik değişkenler üzerine olmuştur. Insanların karakteristik özellikleri onların uyma davranışını etkilemektedir. (Kağıtçıbaşı, 2013). Uyma davranışı alanında yapılan çalışmalarda bireysel farklılıkların neler olduğunu anlamaya yönelik cinsiyet, yaş, liderlik özellikleri, zekâ gibi birçok değişken üzerinde çalışmalar yapılııştır (Cooper, 1979; Cacioppo ve Petty, 1980; Eagly, Wood ve Fishbaugh, 1981; Eagly ve Chrvala, 1986; Zimbardo ve Leippe, 1991; Doğan, 1987; Kağıtçıbaşı, 2013). Bir örgütte çalışanların kurallara uyma biçimi de demografik değişkenlere göre farklılık gösterebilir. Yaşı yüksek olan ve örgütte çalışma süresi daha fazla olan katılımcılar çalışı̆̆ı örgütün kültürünü daha çok içselleştirip daha çok uyma davranışı gösterebilir. Buna rağmen genç kuşak daha sorgulayıcı bir yapıda olacağından koyulan kuralların gerekliliğine inanmayıp kurallara kısmen uymayabilirler. Eğer genç kuşak kuralların anlamlılı̆ına inanırsa kuralları benimser, kurallara uymanın fayda getireceğine inanırsa özdeşleşerek uyma eğiliminde bulunur ya da yasal otoriteden korkup yeni ve tecrübesiz olacağından ceza almaktan çekineceği için kurallara itaat edebilir.

Havacılık sektörü genel olarak vardiyalı çalışmayı gerektiren işleri kapsar. Normal mesaide çalışanlar ertesi gün yine aynı düzen ile kendisi birebir muhatap olacağından başının ağrımaması için kural ne ise onu yapabilir. Nöbetli çalışan personel ise "başkasına iş yıkma" düşüncesinde olur ise bazı kuralları görmezden gelebilir. Mesai türü değişkeni dışında çalışanların görev yaptığı yere göre kurallara uyma biçiminin değişip değişmediği merak edilmiştir.

Havacılık sektöründe teknik, idari personel gibi her kurumda yer alabilecek hizmet türlerinin dışında görev tanımları gereği dünya çapında kabul edilmiş en riskli ve stresli meslekler arasında yer alan Hava Trafik Kontrolörlüğü ${ }^{2}$ çalışanlarının yer aldığı Hava Seyrüsefer çalışanları bulunmaktadır. Ancak, ülkemizde Hava Trafik Kontrollüğü mesleği statüsü gereği idari hizmetler sınıfında yer almaktadır. Bu sektörde her bölüm birbirleriyle koordine faaliyetler yürütür. Teknik bir arıza örneğin elektriğin kısa süreli kesilmesi hiyerarşik anlamda birçok kuruma veya kişiye hesap verme zorunluluğu getirmektedir. Çünkü elektriğin kısa süreli kesilmesi Hava Seyrüsefer hizmetlerinde aksamaya neden olabilir.

\subsection{Araştırmanın Hipotezleri ve Modeli}

Yukarıdaki açıklamalardan yola çıkarak kuramsal ve kavramsal geçerliliği sınamak üzere aşağıdaki hipotezler oluşturulmuştur.

Hipotez 1: Yönetici desteği çalışanların kurallara uyma davranışını benimseme yönünde pozitif ve anlamlı olarak etkiler.

Hipotez 2: Yönetici desteği çalışanların kurallara uyma davranışını özdeşleşme yönünde pozitif ve anlamlı olarak etkiler.

Hipotez 3: Yönetici desteği çalışanların kurallara uyma davranışını itaat yönünde negatif ve anlamlı olarak etkiler.

Demografik özelliklere göre çalışanların yönetici desteği algısının farklılık gösterip göstermeyeceği ve demografik özelliklerin çalışanların kurallara uyma davranış biçiminde farklılık yaratıp yaratmadığı konusunda aşağıdaki hipotezler geliştirilmiştir. 
Hipotez 4: Demografik özelliklere göre algılanan yönetici desteği farklıık göstermektedir.

Hipotez 5: Kurallara uyma davranışının benimseme boyutu çalışanların demografik özelliklerine göre farklılık göstermektedir.

Hipotez 6: Kurallara uyma davranışının özdeşleşme boyutu çalışanların demografik özelliklerine göre farklılık göstermektedir.

Hipotez 7: Kurallara uyma davranışının itaat boyutu çalışanların demografik özelliklerine göre farklılık göstermektedir.

Kuramsal çerçeve ve açıklamalardan yola çıkarak yapılandırılan araştırma modeli Şekil 1'de sunulmuştur.

Şekil 1. Araştırmanın Modeli

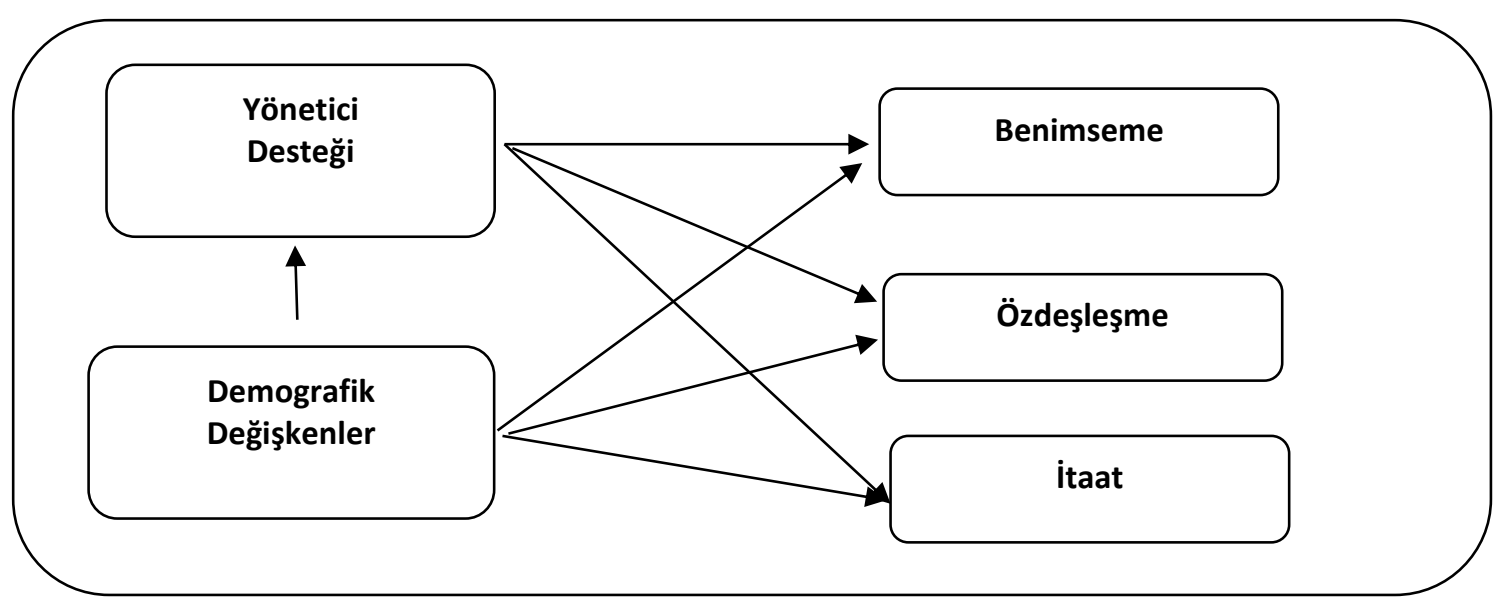

\subsection{Sektörel Bilgi}

Havacılık sektörü, sistematik risk (politik, kur, faiz oranı riski gibi) ve sistematik olmayan (yönetim riski, finansal risk gibi) tüm riskleri içinde barındırmaktadır. Aynı zamanda stratejik risk, finansal risk ve operasyonel risk gibi bir takım risk faktörleri ile karşı karşıya kalan bu sektörde kurallar stratejik risk faktörleri içerinde yer alır (Üçkardeş, 2012: 16-18). Dikkatsizlik, umursamazlık, görmezden gelme gibi durumların olması, hataların arka arkaya gelmesine yol açabilmektedir. Bu sektörde yapılan bir hata bir değil bir çok kişiyi etkileyen geri dönmesi imkansız sonuçlara sebep olabilmektedir.

Havacılık sektöründe önemli bir takım kurallar vardır. Bunlar; (1) emniyet kuralları, (2) güvenlik kuralları, (3) uçuş kuralları, (4) trafik kuralları ve (5) iş kuralları şeklinde sıralanabilir. Havacılık sektöründe havacılık kurallarını belirleme, düzenleme, uygulama ve denetleme adına ICAO (Uluslararası Sivil Havacılık Teşkilatı), ECAC (Avrupa Sivil Havacılık Konferansı), EUROCONTROL (Avrupa Hava Seyrüsefer Güvenliği Örgütü), EASA (Avrupa Havacılık Emniyeti Ajansı), IATA (Uluslararası Hava Taşımacılığı Birliği), ACı (Uluslararası Havalimanları Konseyi) gibi uluslararası birçok kurum ve kuruluş bulunmaktadır ve Türkiye de bu kuruluşların üyesi konumundadır.

Ülkemizde, sivil havacılık alanında kural koyma, denetleme ve yaptırım uygulama faaliyetlerinden sorumlu olan SHGM, havacılık faaliyetlerini emniyet ve güvenlikten ödün vermeden, uluslararası standartlara uygun ve çevreye duyarlı olarak politika ve düzenlemeler yapma çalışmalarını yürütmektedir (SGHM, 2016 Yılı Faaliyet Raporu: 25).

Uluslararası havacılık standartları ile ilgili olarak ülkemizde son 14 yılda 412 adet yasal düzenleme işleme konulmuştur. 
Tablo 1. 2003-2016 Yayımlanan Mevzuat

\begin{tabular}{|c|c|c|c|c|c|c|c|c|c|c|c|c|c|c|}
\hline & $\stackrel{m}{\text { on }}$ & ষ্ণ & 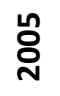 & ¿্ণ & ¿্̀ & 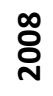 & ষ্ণ & 옹 & $\vec{d}$ & ָั & $\stackrel{m}{\stackrel{n}{N}}$ & $\underset{\sim}{\stackrel{N}{~}}$ & กั & 莕 \\
\hline Direktifler & & & & & & & & & 1 & 1 & 2 & & 1 & \\
\hline Kanunlar & & 1 & & & & & & & 1 & & & & & \\
\hline \begin{tabular}{|c|} 
Bakanlar \\
Kurulu Kararı
\end{tabular} & & & & & & & & & & & & 1 & & \\
\hline Yönetmelikler & & 1 & 2 & 7 & 6 & 2 & 1 & 3 & 5 & 9 & 14 & 5 & 5 & 7 \\
\hline Talimatlar & 6 & 1 & 6 & 2 & 4 & 1 & 12 & 12 & 14 & 19 & 25 & 24 & 29 & 19 \\
\hline Genelgeler & & & 1 & 1 & 8 & 9 & 9 & 5 & 10 & 17 & 14 & 31 & 35 & 23 \\
\hline Toplam & 6 & 3 & 9 & 10 & 18 & 12 & 22 & 20 & 31 & 46 & 55 & 61 & 70 & 49 \\
\hline
\end{tabular}

Kaynak: SGHM 2016 Yılı Faaliyet Raporu, s.52.

Coğrafi konum itibariyle stratejik bir öneme sahip olan ülkemiz her geçen gün artan hava trafiği ile de hava taşımacılığı yarışında önemini ortaya koymaktadır.

\section{Yöntem}

Bu kısımda araştırma evreni ve örneklemi, araştırmada kullanılan ölçekler hakkında bilgi verilmiştir.

\subsection{Evren ve Örneklem}

Havacılık sektöründe; havalimanı işletmeciliği yapan kurum ve özel sektör işletmeleri, hava taşıma/araçları işletmeleri, hava taksi işletmeleri, genel havacılık işletmesi, balon işletmeleri, zirai ilaçlama işletmeleri, yer hizmeti veren kuruluşlar, bakım ve eğitim işletmeleri bulunmaktadır (ilerler, 2017: 128).

Araştırma evrenini; i̇zmir Adnan Menderes Havalimanındaki çalışanlar oluşturmaktadır. Örgüt stratejisi, örgüt büyüklüğü gibi bazı sebeplere bağlı olarak bazı şirketlerde işler daha çok merkezden yürütüldüğü için çalışan sayısının az olduğu saptanmıştır. Bu nedenle araştırmanın amacına uyacak şekilde yönetici - ast ilişkisinin sağıkıı bir şekilde incelenebilmesi için en az 10 çalışanı olan firmalar seçilmiştir.

Adnan Menderes Havalimanında (ADB) çalışan sayısı yıl içerisinde değişkenlik gösterebilmektedir. Işlerin yoğunluğuna göre mevsimsel çalışanların alınmasıyla çalışan sayısı artıp azalabilmektedir. 5000-6000 arası çalışan sayısı içinde 371 anket analiz için kullanılmıştır. \%95 güven aralığı ve 0,05 örnekleme hatası ile örneklem sayısı uygun olmaktadır. 5000 kişi için $n=371>n=357$ şeklinde ifade edilebilir (Arslantürk, 2001: 131).

\subsection{Veri Toplama Aracı}

Çalışmada veri toplama aracı olarak nicel araştırma yöntemlerinden anket tekniği kullanıımıştır. Anket formunda ölçeklere ait ifadeler ve örneklemin demografik yapısını belirlemeye yönelik ifadeler bulunmaktadır. Demografik faktörler; çalışılan kurum, mesai türü, hizmet türü, yaş, cinsiyet, medeni durum, eğitim seviyesi, gelir seviyesi, toplam deneyim ve çalışılan kurumdaki deneyimi belirlemek üzere dokuz kategoride araştırılmıştır.

Bu çalışmada ölçeklerin; güvenilirliğini test etmek için Cronbach'ın (1951) alfa katsayısı yöntemi, geçerliğini test etmek için ise Doğrulayıcı Faktör Analizi (DFA) yönetimi kullanılmıştır. Raporlanan değerler ve kabul edilen sınırlar içerisinde alması gereken değerlere (Sümer, 2000: 59-62; Çokluk, Şekercioğlu ve Büyüköztürk, 2010: 271-272; Meydan ve Şeşen, 2015: 37) dikkat edilmiştir.

Yönetici Desteği Ölçeği: Grandey'in $(1999,2000)$ çalışmasının Öz (2007) tarafından Türkçe'ye uyarlaması yapılan toplam yedi ifadeden oluşan bir ölçek kullanılmıştır. Kullanılan ölçekte altılı Likert ölçeği kullanılmış olup ifadeler "Hemen Hemen Her Zaman"dan "Hemen Hemen Hiçbir Zaman"a uzanmaktadır. Bu 
çalışmada ölçeğin Cronbach ( $\alpha$ ) katsayısı 0,92 bulunmuştur. Çarpıklık (skewness) ve basıklık (kurtosis) değerleri \pm 1 arasında bulunmuştur ve dağılım normaldir.

Grandey $(1999,2000)$ tarafından geliştirilen Öz (2007) tarafından uyarlaması yapılan bu ölçek ulusal literatürde Türkay vd. (2011); Gülova vd.'nin (2013) çalışmalarında da kullanılmıştır.

Uyma Davranışı Ölçeği: Kelman'ın (1958) üç uyma davranışı tanımına dayanılarak Öz (2007) tarafından geliştirilmiş bir ölçektir. Uyma davranışı ölçeğinde bulunan ifadeler, çalışanların belirlenen kurallara hangi nedenden dolayı uyma gösterdikleri ile ilgilidir. Benimseme, özdeşleşme ve itaat davranışı ile ifade edilen üç boyutlu bir ölçektir.

Öz'ün (2007) çalışmasında Kelman'ın (1961) tanımlarına uyan üç faktörün toplam varyansın 71,459 'unu açıkladığı, faktörlerin iç tutarlılık değerlerinin ise benimseme $(0,8318)$, itaat $(0,7776)$ ve özdeşleşme $(0,7702)$ şeklinde çıktığı belirtilmiştir. Kullanılan ölçekte altılı Likert ölçeği kullanılmış olup ifadeler "Hemen Hemen Her Zaman”dan "Hemen Hemen Hiçbir Zaman”a uzanmaktadır. Uyma davranışı ölçeğinin güvenilirliğini belirlemek amacıyla Cronbach $\alpha$ değeri hesaplanmıştır. Ölçekte yer alan dokuzuncu ifadenin düzeltilmiş madde-toplam korelasyon katsayısı hem negatif hem de çok düşük olması nedeniyle dokuzuncu ifade (doğruluğundan gerçekten emin olduğum iş yeri kurallarına uyarım) ölçekten çıkartılmıştır.

Ölçeğin Cronbach $(\alpha)$ değeri 0,66 çıkmıştır. Faktörlerin ayrı $(\alpha)$ değerleri ise benimseme $(0,80)$, özdeşleşme, $(0,67)$, itaat $(0,76)$ şeklinde çıkmıştır. Çarpıklık ve basıklık değerleri \pm 1 arasında bulunmuştur ve dağılım normaldir.

Tablo 2. Yönetici Desteği ve Uyma Davranışı Ölçeğinin Geçerlik ve Güvenirlik Analizi Sonuçları

\begin{tabular}{|c|c|c|c|c|c|c|c|c|c|c|}
\hline & $\mathbf{X}^{2} /$ SD & RMSEA & GFI & AGFI & NFI & TLI & CFI & IFI & Cronbach $\boldsymbol{\alpha}$ & HOLTER \\
\hline YD & 3,099 & 0,075 & 0,98 & 0,94 & 0,98 & 0,98 & 0,98 & 0,98 & 0,92 & 255 \\
\hline UD & 2,423 & 0,062 & 0,96 & 0,93 & 0,93 & 0,94 & 0,95 & 0,95 & 0,66 & 269 \\
\hline
\end{tabular}

*Kritik örneklem büyüklüğü. Yani örneklem büyüklüğü için alt sınırı ifade etmektedir (Hoelter, 1983; Hu ve Bentler, 1995 akt. Kaya ve Altınkurt, 2018).

Tablo 2' de yönetici desteği ve uyma davranışı ile ilgili DFA sonuçları incelendiğinde uyum değerlerinin kabul edilen sınır değerler içerisinde yer aldığı görülmektedir. Ayrıca, ölçeklerin Cronbach $\alpha$ değerlerine bakıldığında Kalaycı (2010) referans değerlerine göre ölçekler güvenilirdir.

\section{Analiz ve Bulgular}

\subsection{Tanımlayıcı İstatistikler}

Örnekleme ilişkin demografik değişkenler incelendiğinde; Ankete katılanların \%50,9’u normal mesai çalışanları (08:00-17:00) iken \%49,1'i 7/24 denilen mesai türünde vardiya sistemi ile çalışmaktadır. Hizmet sınıflarına bakıldığında ankete katılanların \%25,3'ü teknik hizmetler (mühendis, başmühendis, mimar, tekniker, teknisyen, teknisyen yardımcısı, teknik ressam, uçuş eğitmeni) sınıfında çalışmakta iken \%22,9'u idari hizmetler denilen personel, muhasebe-finans, evrak takibi, satın alma gibi işlerde çalışmaları yürütmektedir. Hava seyrüsefer hizmetlerinde görev yapanların katılımı \%16,5 olmuştur. Havalimanında çalışan sağlık personeli ile güvenlik görevlilerinin katılım toplam oranı ise \%17'dir. Havaalanı kurtarma ve yangınla mücadele hizmetleri sınıfında çalışıp ankete katılanların oranı ise $\% 2,7^{\prime}$ 'dir.

Yaş durumları incelendiğinde 26-35 yaş arası çalışanlar örneklemin \%20,5'ini, 36-45 yaş arası çalışanlar \%33,2'sini, $46-55$ yaş arası çalışanlar \%31'ini, 56 yaş ve üstü çalışanlar ise \%15,3'ünü oluşturmaktadır. 
Ankete katılanların büyük bir bölümü erkek $(\% 80,6)$ ve evlidir $(\% 79,8)$. Eğitim seviyesi incelendiğinde örneklemin \%45,6'sı lisans mezunu iken, \%24,3'ü önlisans mezunu, \%19,7'si lise mezunu, \%5,4'ü lisansüstü $\% 5,0^{\prime}$ i ilkokul/ortaokul mezunudur.

Gelir seviyesi incelendiğinde örneklemin \%52,8'i 2001-4000 TL arası, \%26,4'ü 4001-6000 TL arası, \%13,3'ü 6001 TL ve üzeri ücret almaktadır. Çok az bir kısmın $(\% 7,5) 2000$ TL'den düşük ücret aldığı görülmektedir. Havacılık sektöründe deneyimli personel sayısı (26 yıl ve üstü) yüksektir (Toplam Deneyim: \%38,3, Çalışılan Kurumdaki Deneyim: \%32,1).

Tablo 3. Örneklemin Demografik Özellikleri

\begin{tabular}{|c|c|c|c|}
\hline Değişken & & Frekans & Oran(\%) \\
\hline \multirow{2}{*}{ Mesai Türü } & Normal Mesai & 189 & 50,9 \\
\hline & Nöbetli Mesai & 182 & 49,1 \\
\hline \multirow{6}{*}{ Hizmet Türü } & Yönetim Hizmetleri* & 58 & 15,6 \\
\hline & Teknik Hizmetler** & 94 & 25,3 \\
\hline & Havacılık Acil Yardım ve Güvenlik Hizm.*** & 63 & 17 \\
\hline & İdari Hizmetler $* * * *$ & 85 & 22,9 \\
\hline & Havaseyrüsefer Hizmetleri****** & 61 & 16,5 \\
\hline & Havaalanı Kurtarma Yangınla Mücadele Hizm. & 10 & 2,7 \\
\hline \multirow{4}{*}{ Yaş } & $26-35$ & 76 & 20,5 \\
\hline & $36-45$ & 123 & 33,2 \\
\hline & $46-55$ & 115 & 31,0 \\
\hline & 56 ve üstü & 57 & 15,3 \\
\hline \multirow{2}{*}{ Cinsiyet } & Erkek & 299 & 80,6 \\
\hline & Kadın & 72 & 19,4 \\
\hline \multirow{2}{*}{ Medeni Durum } & Evli & 296 & 79,8 \\
\hline & Bekar & 75 & 20,2 \\
\hline \multirow{5}{*}{ Eğitim Seviyesi } & ilkokul/Ortaokul & 19 & 5,0 \\
\hline & Lise & 73 & 19,7 \\
\hline & Önlisans & 90 & 24,3 \\
\hline & Lisans & 169 & 45,6 \\
\hline & Lisans Üstü & 20 & 5,4 \\
\hline \multirow{4}{*}{ Gelir Seviyesi } & $1000-2000$ TL arası & 28 & 7,5 \\
\hline & 2001-4000 TL arası & 196 & 52,8 \\
\hline & 4001-6000 TL arası & 98 & 26,4 \\
\hline & 6001 TL ve üstü & 49 & 13,3 \\
\hline \multirow{6}{*}{ Toplam Deneyim } & $1-5 \mathrm{yıl}$ & 22 & 5,9 \\
\hline & 6-10 yıl & 40 & 10,8 \\
\hline & $11-15 \mathrm{yll}$ & 50 & 13,5 \\
\hline & $16-20$ yıl & 69 & 18,6 \\
\hline & $21-25 \mathrm{yll}$ & 48 & 12,9 \\
\hline & 26 yıl ve üstü & 142 & 38,3 \\
\hline \multirow{6}{*}{$\begin{array}{l}\text { Çalışılan } \\
\text { Kurumdaki } \\
\text { Deneyim }\end{array}$} & $1-5 \mathrm{yll}$ & 60 & 16,2 \\
\hline & 6-10 yıl & 41 & 11,0 \\
\hline & 11-15 yıl & 58 & 15,6 \\
\hline & $16-20 \mathrm{yll}$ & 62 & 16,7 \\
\hline & $21-25 \mathrm{yll}$ & 31 & 8,4 \\
\hline & 26 yıl ve üstü & 119 & 32,1 \\
\hline
\end{tabular}

* Başmüdür, Baş Müdür Yrd., Nöbetçi Meydan Müd., Şube Müdürü, Müdür Yrd., Şef, Teknik Şef, ** Mühendis, Baş Mühendis, Mimar, Tekniker, Teknisyen, Teknisyen Yrd., Teknik Ressam, Uçuş Eğitmeni, ***Doktor, Hemşire, Yrd. Sağlık Personeli, Güvenlik Personeli, $* * * * *$ Şoför, Büro Hizmetlerinde Çalışan, Terminal Hizmetlerinde Çalışan, ****** Hava Trafik Baş Kontrolü, Hava Trafik Kontrolü, AIM Memuru 
Yönetici Desteği ve Uyma Davranışı ölçeğinde yer alan ifadelerin değerlendirilmesi altılı Likert ölçeğinde $5 / 6=0,833$ ile hesaplanan formüle göre aşağıdaki gibi yapılmıştır.

- Hemen hemen hiçbir zaman $1,00-1,833$

- Nadiren 1,834-2,667

- Bazen 2,668-3,501

- Oldukça Sık 3,502-4,335

- Çok Sık 4,336-5,169

- Hemen hemen her zaman 5,17-6,00

Kurallara uyma davranışına ilişkin tanımlayıcı istatistikler Tablo 4'te gösterilmiştir.

Tablo 4. Kurallara Uyma Davranışının Tanımlayıcı İstatistikleri

\begin{tabular}{|l|c|c|c|c|c|c|c|}
\hline & $\mathrm{N}$ & Min. & Max. & $\begin{array}{c}\text { Ortalama } \\
\overline{\mathrm{X}}\end{array}$ & $\begin{array}{l}\text { Medyan } \\
\text { (Ortanca) }\end{array}$ & Mod & S.S. \\
\hline $\begin{array}{l}\text { Genel olarak örgütsel } \\
\text { kurallara ne sıklıkta } \\
\text { uyuyorsunuz? }\end{array}$ & 371 & 1,00 & 6,00 & 4,8248 & 5,00 & 6,00 & 1,29440 \\
\hline Benimseme & 371 & 1,00 & 6,00 & 3,2650 & 3,3333 & 1,00 & 1,53404 \\
\hline Özdeşleşme & 371 & 1,00 & 6,00 & 4,0458 & 4,3333 & 4,33 & 1,28400 \\
\hline İtaat & 371 & 1,00 & 6,00 & 2,8032 & 2,7500 & 1,00 & 1,23273 \\
\hline
\end{tabular}

Kurallara uyma davranışı kapsamında ankete katılanlara "Genel olarak örgütsel kurallara ne sıklıkta uyuyorsunuz?" sorusu yöneltilmiş ve katılımcılar "çok sık" $\bar{X}=4,8248$ şeklinde yanıtlamışlardır. Tablo 4'e bakıldığında katılımcıların kurallara en fazla özdeşleşme yoluyla uydukları, Mod=Ortanca $=4,33$ ve $\bar{X}=4,0458$ puanından anlaşılmaktadır. Katılım düzeyi "oldukça sık" ifadesine denk gelmektedir. Kurallara uyma biçimi ikinci olarak benimseme $(\bar{X}=3,2650)$ çıksa da itaat $(\bar{X}=2,8032)$ yoluyla uyma biçimi ile beraber "bazen" olan aynı katılım düzeyini paylaşmışlardır.

Özdeşleşme boyutunda faktör ağırlıklarına göre sırasıyla; katılımcıların yöneticilerini sevmelerinin kurallara uymalarını kolaylaştırdığı fikri daha çok kabul görmüştür $(\% 32,6)$. İşyerinde sevilen kişilerin kurallara uyması kişinin aynı kurallara uymasını kolaylaştırmaktadır (\%27,5). Ayrıca, kişinin kurallara uymadığı zaman yakınlık duyduğu kişilerin rahatsız olacağı fikri kişiyi kurallara uymaya zorlamaktadır $(\% 19,7)$. Ortalamalar "oldukça sık" puanına denk gelmektedir $(\bar{X}=3,502$ - 4,335).

Itaat boyutunda kurallara uyulmadığı zaman yöneticiler bazen $(\bar{X}=2,668-3,501)$ cezalandırma $(\bar{X}=3,1860)$, azarlama $(\bar{X}=3,1051)$ eğilimde olmasından dolayı veya göze batmamak için $(\bar{X}=2,7035)$ kişi bir kurala inanmasa da o kurala uymak zorunda kalabilmektedir.

Benimseme boyunda, kişinin kendi değerleri ile örtüşen, olması gerektiğine inandığı ve uyulduğunda iyi sonuç veren işyeri kurallarına uyma düzeyi ortalama bir düzey çıkmıştır.

Yönetici desteği algısına yönelik tanımlayıcı istatistikler Tablo 5'te verilmiştir.

Tablo 5. Yönetici Desteği Algısına Yönelik Tanımlayıcı İstatistikler

\begin{tabular}{|l|c|c|c|c|c|c|c|}
\hline & $\mathrm{N}$ & Min. & Maks. & $\begin{array}{c}\text { Ortalama } \\
(\overline{\mathrm{X}})\end{array}$ & $\begin{array}{c}\text { Medyan } \\
\text { (Ortanca) }\end{array}$ & Mod & Std. Sapma \\
\hline YD & 371 & 1,00 & 6,00 & 4,3739 & 4,5714 & 6,00 & 1,32092 \\
\hline
\end{tabular}


Tablo 5 incelendiğinde; katılımcıların yönetici desteği algısına ilişkin ankete katılanların paylaştığı görüşler içinde en çok tekrar edilen ifade (mod=6) "Hemen hemen her zaman" ifadesidir. Genel olarak yönetici desteği algısına ilişkin katılım düzeyinin ise "Çok Sık", $\bar{X}=4,3739$ olduğu görülmektedir. Yönetici desteğine ilişkin verilen cevaplar arasından en çok puanı alan ifade "Yöneticime kolaylıkla danışabilirim" olmuştur $(\bar{X}=4,7682)$. Sonra sırasıyla katılımcılar; işler karıştığında yöneticisine rahatlıkla söyleyebileceğini $(\bar{X}=4,5957)$, zor durumlar yaşandığında yöneticinin bu durumu çözeceğini $(\bar{X}=4,5553)$, yöneticilerinin çalışanlarına sahip çıktığını $(\bar{X}=4,4420)$, zor durumlarla karşılaştıklarında bulunduğu durumdan yöneticilerinin kurtulmasına yardımcı olacağını $(\bar{X}=4,3962)$, yaşadığı zor durumlardan yöneticisine bahsedebileceğini $(\bar{X}=4,0916)$, molaya ihtiyaç duyduğunda yöneticisinin işini üstlenebileceğini $(\bar{X}=3,7682)$ düşünmektedirler.

\subsection{Hipotez Testleri}

\subsubsection{Yönetici Desteğinin Çalışanların Kurallara Uyma Davranışı Üzerindeki Etkisi}

Yönetici desteğinin çalışanların kurallara uyma davranışı üzerindeki etkisi korelasyon analizi ve AMOS programı aracılığı ile yapısal eşitlik modeli analizi sonuçları ile değerlendirilmiştir.

Korelasyon analizi;

Yönetici desteği ile Kurallara Uyma Davranışının alt boyutları arasındaki ilişkiler incelendiğinde; yönetici desteği ile benimseme davranışı arasında bir ilişkiye rastlanmaz iken özdeşleşme ve itaat davranışı arasında anlamlı ilişkiye rastlanılmıştır. Yönetici desteği ile özdeşleşme davranışı arasındaki ilişki $r=0,160$ pozitif yönde ve $p<0,01$ düzeyinde anlamlı iken yönetici desteği ile itaat davranışı arasındaki ilişki $r=0,193$ negatif yönde ve $p<0,01$ düzeyinde anlamlıdır.

Yapısal eşitlik modeli;

Modelin uyum değerleri iyi uyumu göstermektedir. Yönetici desteğinin çalışanların kurallara uyma biçimini özdeşleşme yönünde pozitif yönde $(\beta=0,30, p<0,01)$ (H2 KABUL) ve itaat yönünde negatif yönde ( $\beta=$ $-0,19, p<0,01$ ) etkiledikleri (H3 KABUL) anlaşılış̧ır. Ancak yönetici desteğinin çalışanların kurallara uyma davranışını benimseme yönünde etkilemesi yönündeki ilişki anlamsız çıkmıştır ( $\beta=-0,02, p>0,05)$ (H1 RED).

Şekil 2. Yönetici Desteğinin Çalışanların Kurallara Uyma Davranışı Üzerindeki Etkisi

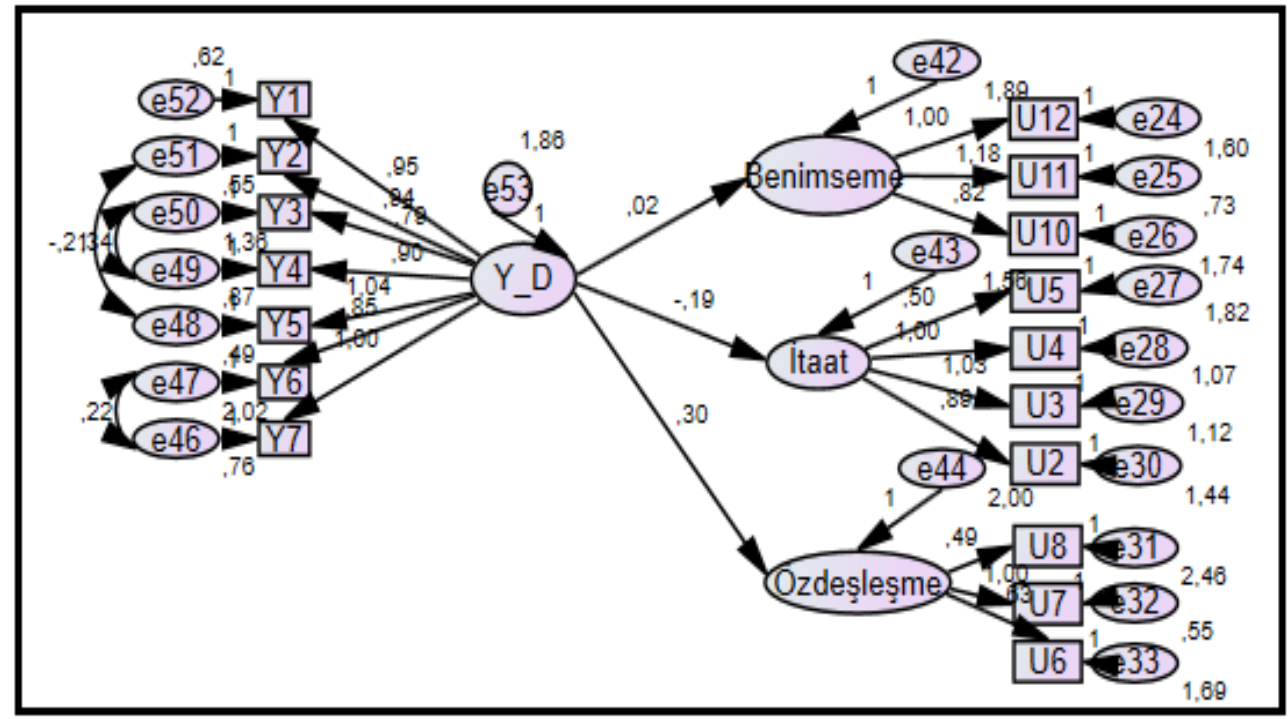

$\chi^{2} / S D: 1,92$, RMSEA: 0,05, GFI: 0,93, AGFI: 0,91, NFI: 0,93, TLI:0,96, CFI: 0,96, IFI: 0,97, HOLTER: 259 
Tablo 6. Yönetici Desteğinin Çalışanların Kurallara Uyma Davranışı Üzerindeki Etkisi

\begin{tabular}{|c|c|c|c|c|c|c|c|c|}
\hline & & & Tahmin & S.H. & K.O. & $\mathbf{P}$ & $\begin{array}{c}\boldsymbol{\beta} \\
\text { (Regresyon } \\
\text { Katsayısı) }\end{array}$ & $\begin{array}{c}\text { Korelasyon } \\
\text { Değeri }\end{array}$ \\
\hline BD & $\begin{array}{c}\leftarrow- \\
-\end{array}$ & YD & 0,020 & 0,058 & 0,347 & 0,728 & $-0,020$ & $-0,029$ \\
\hline ÖD & $\begin{array}{c}\leftarrow- \\
-\end{array}$ & YD & 0,299 & 0,063 & 4,774 & 0,000 & 0,299 & $0,160^{* *}$ \\
\hline ID & $\begin{array}{c}\leftarrow- \\
-\end{array}$ & YD & $-0,194$ & 0,056 & $-3,488$ & 0,000 & $-0,194$ & $-0,193^{* *}$ \\
\hline
\end{tabular}

BD: Benimseme Davranışı, Özdeşleşme Davranışı, ID: İtaat Davranışı, YD: Yönetici Desteği

Demografik değişkenlere göre çalışanların yönetici desteği algısının farklı olup olmadığı ve demografik değişkenlerin çalışanların kurallara uyma davranış biçimleri arasında farklılık yaratıp yaratmadığını anlamak için t-testleri ve ANOVA testleri yapılmıştır.

\subsubsection{Demografik Özelliklere Göre Yönetici Desteği AlgıSı}

Çalışanların yönetici desteği algısının demografik özelliklerine göre farklılıkları incelendiğinde; çalışanların gelir $(F=3,605, p=0,014<0,05)$ ve hizmet türüne $(F=2,852, p=0,015<0,05)$ göre anlamlı düzeyde farklılık gösterdiği ortaya çıkmıştır.

- Gelir durumu 2001-4000 TL arası olanlar ( $\bar{X}=4,5758), 4001-6000$ TL arası olanlara $(\bar{X}=4,1020)$ göre yönetici desteği algısında farklııı ortaya çıkmıştır.

- Havacılık Acil Yardım ve Güvenlik Hizmetleri $(\bar{X}=4,5805)$ çalışanları havaseyrüsefer hizmetleri sınıfında $(\bar{X}=3,8314)$ çalışanlara göre yönetici desteği algısında farklılık ortaya çıkmıştır.

- İdari Hizmetler Sınıfı $(\bar{X}=4,5597)$ çalışanları ise havaseyrüsefer hizmetleri sınıfında $(\bar{X}=3,8314)$ çalışanlara göre yönetici desteği algısında farklılık ortaya çıkmıştır.

\subsubsection{Demografik Özelliklere Göre Kurallara Uyma Biçimleri Arasındaki Farklılıklar}

Çalışanların demografik özelliklerine göre kurallara uyma biçimleri arasında farklıııkları incelendiğinde; Benimseme davranışının eğitim durumu ( $F=7,458, p=0,000<0,05)$; Özdeşleşme davranışının cinsiyet $(\mathrm{t}=2,119$ ve $0,035<0,05)$; İtaat davranışının medeni durum ( $\mathrm{t}=-2,348 ; 0,019<0,05)$, mesai türü ( $\mathrm{t}=$ $-2,271 ; 0,024<0.05)$ ve hizmet türü $(F=3,095, p=0,009<0,05)$ değişkenleri arasındaki farklııklar anlamlıdır.

1-a) Eğitim durumu IIlkokul/Ortaokul olanlar $(\bar{X}=4,5088)$, önlisans $(\bar{X}=3,1889)$ ve lisans olanlara $(\bar{X}$ ] $=$ 2,9329) göre,

b)Eğitim durumu lise $(\bar{X}=3,6530)$ olanlar ise eğitim durumu lisans $(\bar{X}=2,9329)$ olanlara göre benimseme davranışında farklılık ortaya çıkmıştır.

Eğitim seviyesi düştükçe çalışanların kurallara benimseme yoluyla uyduğu görülmektedir. uymaktadırlar.

2- Erkekler $(\bar{X}=4,1148)$ kadınlara $(\bar{X}=3,7593)$ göre kurallara daha çok özdeşleşme yoluyla

Elde edilen bu sonuç erkeklerin kadınlara göre kurallara uyma biçiminin daha çok başkasına benzemek, örnek almak yoluyla olduğunu göstermektedir. Amir, 1984 yılında yapmış olduğu çalışmasında cinsiyet konusunda beklenildiği üzere belirgin bir farkın ortaya çıkmadığını belirtmiştir. Bu çalışmada kadın katılımcıların ortalaması erkek katııımılardan fazla çıkmıştır. Ancak, çalışmada erkek katıımcıların kadın katılımcılardan fazla olduğu göz önünde bulundurulmalıdır.

3-a) Evlilerin itaat boyutuna ilişkin ortalaması $(\bar{X}=2,7280)$ bekârların ortalamasından $(\bar{X}=3,1000)$ daha düşüktür. Yani bekarların kurallara daha çok itaat yoluyla uyma biçimini seçtiği görülmektedir. 
b) Nöbetli mesai olarak çalışanların ortalaması $(\bar{X}=2,9505)$ normal mesai olarak çalışanların ortalamasından $(\bar{X}=2,6614)$ daha yüksektir. Yani nöbetli mesai çalışanlarının normal mesai çalışanlarına göre daha çok itaat yoluyla uyma biçimini tercih ettiği görülmektedir.

c) Havaseyrüsefer hizmetleri sınıfında $(\bar{X}=3,2746)$ çalışanlar Yönetim hizmetleri sınıfında $(\bar{X}=2,4655)$ çalışanlara göre,

d) Havaseyrüsefer hizmetleri sınıfında $(\bar{X}=3,2746)$ çalışanlar Havacılık Acil Yardım ve Güvenlik Hizmetleri $(\bar{X}=2,6071)$ sınıfında çalışanlara göre kurallara itaat yoluyla uyma davranışında farklııklar tespit edilmiştir.

Tablo 7. Hipotezlerin RED-KABUL Özet Tablosu

\begin{tabular}{|c|c|}
\hline $\mathrm{H} 1: \mathrm{YD} \longrightarrow \mathrm{BD}$ & RED \\
\hline $\mathrm{H} 2: \mathrm{YD} \longrightarrow$ ÖD & KABUL \\
\hline $\mathrm{H} 3: \mathrm{YD} \longrightarrow \mathrm{ID}$ & KABUL \\
\hline $\mathrm{H} 4: \mathrm{DD} \longrightarrow \mathrm{YD}$ & KABUL (Gelir ve Hizmet Türü) \\
\hline $\mathrm{H} 5: \mathrm{DD} \longrightarrow \mathrm{BD}$ & KABUL (Eğitim Durumu) \\
\hline H6: DD $\longrightarrow$ ÖD & KABUL (Cinsiyet ) \\
\hline $\mathrm{H7:DD} \longrightarrow \mathrm{iD}$ & KABUL (Medeni Durum, Mesai ve Hizmet Türü) \\
\hline
\end{tabular}

\section{Sonuç ve Öneriler}

Araştırma sonunda, yönetici desteğinin çalışanların kurallara uyma biçiminde etkisi iki biçimde ortaya çıkmıştır. Bu etki, özdeşleşme yönünde pozitif yönde ve itaat yönünde negatif yöndedir. Çalışanlar yöneticilerinden olumlu etkilenerek örgütsel kurallara uyarken "özdeşleşme" tipi uyma davranışını seçmekte ve bu olumlu etki çalışanların kurallara "itaat" etme eğilimini azaltmaktadır. Yöneticiler örgütlerde üst yönetim ile çalışanlar arasında köprü vazifesi görürler. Çalışanlar ile en yakın ilişkide bulunanlar yöneticilerdir. Elbette yöneticilerin davranış tarzları örgüt tarafından uyulmasını beklediği kurallara yol gösterecektir. Yönetici desteğini hisseden çalışanların yöneticilerin cezalandırma gücü, zorlayıcı ve yasal gücünü kullanmayacakları öngörüsü ile yöneticilerine kolaylıkla danışabilmeleri, yöneticileriyle rahat iletişim kurabilmeleri, duydukları güven, beğenme ve bağlıık hisleri ile kurallara özdeşleşme yoluyla uydukları ve kurallara itaat etme eğiliminden uzaklaştıkları düşünülmektedir. Hogg ve Vaughan (2011) bireyin grup üzerindeki normatif etkisi yani "azınlık etkisi" sayesinde çoğunluğun lidere veya meşru yasal otoriteye göre hareket ettiğini belirtmiştir. Yöneticiler, çalışanlar ile yakın ilişkide olarak çalışanların görüşünü değiştirmede etkili olabilmektedir ve kurallara uyma biçiminde etkili olabilmektedir.

Araştırmanın ana amacı olan yönetici desteğinin çalışanların kurallara uyma davranışı üzerinde bir etkisi olup olmadığının araştırıldığı bu çalışma, çalışanların kurallara uyma davranışında yönetici davranışlarının önemli etkisi olduğunu vurgulayan teorik çalışmaları (Bennis, 1969, 1970; Vries ve Miller, 1984; Rahim, 1989; Robbins, 1996; Muse ve Pichler, 2011) ampirik olarak destekleyerek kavramsal literatüre önemli bir dayanak oluşturmuştur. Çalışanların örgütsel kurallara uyma eğilimi yöneticilerin kendileri hakkındaki olumlu izlenimlerine, yöneticileri tarafından örgütte bir değer olarak görülüp görülmediklerine göre değişebilmektedir. Yani bu çalışma ile yönetici davranışlarının çalışan davranışları üzerinde etkili olduğu bir kez daha vurgulanabilir.

Çalışmanın bir diğer amacı olan çalışanların yönetici desteği algısında demografik değişkenlerin etkisinin incelendiği bu çalışmada farklıık, gelir ve hizmet türü değişkenlerinde ortaya çıkmıştır. Başka çalışmalarda hizmet türü anlamında kullanılan unvan veya çalışılan birim arasındaki farklılıkların anlamlılığı konusunda Emhan vd. (2013), Ceylan vd. (2013) ve Arslan (2019) çalışmalarına benzerlik göstermiştir. Böylece bir kurumda kişinin çalıştığı unvan veya çalıştığı birime göre yönetici desteği algısı farklı olabilmektedir. 
Demografik değişkenler ile kurallara uyma davranışı arasındaki ilişkiler incelendiğinde; eğitim değişkenine göre çalışanların kurallara uyma biçimi olan Benimseme türü uymada farklılı̆ın ilkokul/ortaokul mezunlardan kaynaklandığı tespit edilmiştir. Eğitim seviyesi düştükçe örgütsel kuralların daha çok içselleştirildiği görülmektedir. Kişinin değerler sistemi ile uyuşmuştur. Bu durum psikolojik olarak şöyle bir düşüncenin içinde yer alabilir. Bir kural koyulmuş ise sorgulamadan uygulamak gerekir. Kural ne ise o yapılır. Ayrıca; cinsiyet türüne göre çalışanların kurallara uyma biçimi olan özdeşleşme türü uymada farklılık tespit edilmiştir. Erkekler bayanlara göre kurallara özdeşleşme yoluyla uymaktadır. Elde edilen bu sonuç erkeklerin kadınlara göre kurallara uyma biçiminin daha çok başkasına benzemek, örnek almak yoluyla olduğunu göstermektedir. Amir, 1984 yılında yapmış olduğu çalışmasında cinsiyet konusunda beklenildiği üzere belirgin bir farkın ortaya çıkmadığını belirtmiştir. Bu çalışmada erkek katıımcıların kadın katılımcılardan fazla olduğu göz önünde bulundurulmalıdır. İtaat boyutu ile medeni durum, mesai türü ve hizmet türü değişkenleri arasındaki farklılıklar anlamlıdır. Medeni durum değişkenine göre farklılık bekârlardan, mesai türü değişkenine göre nöbetli mesaide çalışanlardan, hizmet türü değişkenine göre hava seyrüsefer hizmetleri sınıfında çalışanlardan kaynaklanmaktadır.

Yöneticiler, örgütün değerleri ve normlarını göz önünde bulundurarak örgüt tarafından belirlenmiş ve kabul edilmiş kuralların uygulanmasında kendilerine önemli görevler düştüğünün bilincinde olmalıdır ve bu bilinç örgüt tarafından desteklenmelidir. Diğer parametrelerin de olduğu varsayılmakla beraber örgüt tarafından belirlenmiş kurallara uyulmasında en önemli rol yöneticilere düşmektedir. Yöneticiler çalışanlara verdiği destekle yani çalışanları ile kurdukları dostane ilişkiler ile bunu başarabilirler. Önemli olan kurallara biçiminin nasıl olduğudur.

Işletmeler, kurallara uyma konusunda ödül ve ceza değil de geribildirim yoluyla çalışanların örgüt kurallarına uymasını pekiştirebilir. Dökmen (2004) ödülün cezadan geribildirimin ise ödülden üstün olduğunu ifade etmektedir. Bu kazanım Dökmen'in (2004) bakış açısıyla aşağıda açıklanmaya çalışılmışır.

Eğer bir örgütte çalışanların örgüt tarafından belirlenmiş kurallara uyması o işletmenin kar elde etmesi adına gösterilen özveri ve/veya örgüte bağlılık kadar önem taşıyorsa yöneticiye elbette işin en büyük kısmı düşmektedir. Psikolojide canlının istenilen bir davranışı yerine getirmesinde ödül, istenilmeyen davranışların bir daha tekrarlanmaması için ceza yöntemleri önemli uyarıcılar olarak yerini almıştır. İnsan psikolojisi ödül ve ceza mekanizmasını çok iyi özümser. Örgütlerde ödül; -çok yapılan bir şey değildir- sözel takdir edilme ve beğenilme ya da ikramiye, ceza ise sözel uyarılma, maaştan kesme, kınama, izin almada kısıtlama ve hatta iş akdinin feshi şeklinde olabilmektedir. Ödül ve ceza bir yoldur ancak olumlu geri dönüşümü tartışılır. Ödül ve ceza sonucunda bir örgütte ortaya çıkan durumlar genelde hasetlik > kıskançlık $>$ dedikodu (ödül sonucu) veya uzun süren tartışmalar > küskünlükler > inatlaşmalar > verimsizlik > atıl çalışma (ceza sonucu) gibi sonuçlar doğurabilir. Oysaki "geribildirim" yöntemiyle yönetici sağılılı bir örgüt ve örgüt kültürü adına doğru adımlar atabilir. Örneğin; mesai saatlerine uymak bir kuraldır. Bir işgörenin mesai saatine uyması bir ödül gerektirmez. Çünkü bu bir kuraldır. Ancak o işgörenin sıklıkla mesaisine geç geldiğini varsayalım. Süreklilik aslında ceza gerektirir. Ancak bu işgören çalışkan biri ancak tek zaafı uyanamamak ise verilen ceza işgörende ters tepebilir. Bazen de ceza ortadan kalktığında fiil tekrarlayabilir. Bunun yerine yönetici, o iş gören bir gün zamanında mesaiye geldiğinde "bugün geç gelmediğin için ücretsiz kahve ikramını kaçırmadın ya da işleri erken bitirebileceğin için bugün erken çıkabilirsin" gibi geribildirimde bulunursa çalışan psikolojik olarak da işe sürekli geç gelmeme edimini kazanabilir.

Aslında beklenen yönetici desteği olan örgütlerde çalışanların kurallara "benimseme" yoluyla uymasıdır. Yasal otorite tarafından belirlenmiş kurallar bellidir. Fakat örgüt, öngördüğü ve özellikle uyulmasını istediği kurallara hassasiyetle dikkat çekerse çalışanların farkındalığının artacağı yöneticisi tarafından da bu durum desteklenirse örgütsel kurallara uyma davranışının artacağı düşünülmektedir. Bununla birlikte işletmeler uygulanması güç kuralları çalışanlara dikte etmemeli, önem verdiği hangi kuralların uygulanmadığı ve uygulanmama sebepleri ve çözüm yolları araştırılmalıdır.

Araştırma bulguları Havacılık sektöründe çalışanların kurallara uyma davranış biçimi seçimine ilişkin önemli fikirler vermekle birlikte, araştırmanın bazı kısıtlarının bulunduğu göz önünde bulundurulmalıdır. Bu 
araştırmanın en büyük kısıtı özel sektör çalışanlarının az olmasıdır. Araştırma farklı illerde ve özel sektör katılımı sağlanabilse görgül bilginin dayanağı daha kapsamlı hale getirilebilir.

Çalışanların kurallara uyma konusundaki seçimi örgütün kamu kurumu ya da özel teşebbüs olmasına göre farklııklar yaratabileceği gibi sektörel farklılıklar da yaşanabilir. Bu açıdan farklı sektörlerde kamu ya da özel işletmeler açısından çalışmaların çeşitlenmesi önerilmektedir.

Bu araştırma havacılık sektöründe çalışanların "örgütsel kurallar" adıyla ne algıladığına ilişkin bir ayrım gözetilmeden yapılmıştır. Havacılık sektöründe emniyet kuralları, güvenlik kuralları, uçuş kuralları ve trafik kuralları olmak üzere birçok kural bulunmaktadır. Illgili personel ile özellikli çalışmalar yapılabilir. Güvenlik kurallarına çalışanların uyma biçimi gibi. Ayrıca yöneticilerin güç eğilimleri ve kişilik özelliklerinin çalışanların kurallara uyma davranış biçimini etkileyip etkilemeyeceği konusu çalışılabilir.

\section{Beyan ve Açıklamalar (Disclosure Statements)}

1. Bu çalışmanın yazarları, araştırma ve yayın etiği ilkelerine uyduklarını kabul etmektedirler (The authors of this article are admitted that they complied with the principles of research and publication ethics).

2. Yazarlar tarafından herhangi bir çıkar çatışması beyan edilmemiştir (No potential conflict of interest was reported by the authors).

3. Bu çalışma, intihal tarama programı kullanılarak intihal taramasından geçirilmiştir (This article was screened for potential plagiarism using a plagiarism screening program).

\section{Son Notlar}

1. Bu çalışma, Doç. Dr. Asena Altın Gülova'nın danışmanlığında yürütülen ve 2017 yllında tamamlanan “Örgüt Külttürü ile Çalışanların Kurallara Uyma Davranışı Arasındaki ilişside Yönetici Desteğinin Rolü: Havacılık Sektöründe Bir Araştırma" başlıklı doktora tezinden üretilmiştir.

2. $h t t p: / / w w w . h t k s . o r g / h t k s / ? a u t h o r=2$ Erişim Tarihi: 14.09.2016

\section{Kaynaklar}

Ackfeldt, A. L., \& Leonard, V. C. (2005). A study of organizational citizenship behaviors in a retail setting. Journal of Business Research, 58, 151-159.

Akgündüz, Y. (2014). Otel çalışanlarının örgütsel sessizliği tercih etmelerinde örgütsel güvenlerinin etkisi. Organizasyon ve Yönetim Bilimleri Dergisi, 6(1), 184-199.

Aksoy, C. (2017). Çalışanlarda adalet ve yönetici desteği algııının güven oluşumundaki rolü: Havacılık sektöründe bir uygulama. Journal of Aviation, 1(1), 8-17.

Amir, T. (1984). The asch conformity effect: A study in Kuwait. Social Behavior and Personality, 12(2), 187-190

Aranson, E., Wilson, T. D., \& Akert, R. M. (2012). Sosyal psikoloji (Çev: Okhan Gündüz). İstanbul: Kaknüs Yayınları.

Arslan, V. (2019). Çalışanların yönetici desteği, duygu düzenleme, iş memnuniyeti ve örgütsel performans algıları arasındaki ilişkilerin analizi: Sağlık bir uygulama. Uluslararası Yönetim ve Sosyal Araştırmalar Dergisi, 6(12), 1-25.

Arslantürk, Z. (2001). Sosyal bilimciler için araştırma metod ve teknikleri (5. Baskı). ìstanbul: Çamlıca Yayınları.

Balcı, A., Baltacı, A., Fidan, T., Cereci, C., \& Acar, U. (2012). Örgütsel sosyalleşmenin, örgütsel özdeşleşme ve örgütsel vatandaşlıkla ilişkisi: Illköğretim okulu yöneticileri üzerinde bir araştırma. Eğitim Bilimleri Araştırma Dergisi (EBAD)/Journal of Educational Sciences Research, 2(2), 47-74.

Ceylan, A. K., Çelik, G. Y., \& Emhan, A. (2015). Personel güçlendirmesi ve yönetici desteğinin iş memnuniyeti üzerindeki etkisi: Enerji sektöründe bir uygulama. İşletme Araştırmaları Dergisi, 7(1), 168-185. 
Ceylan, A., \& Özbal, S. (2008). Özdeşleşme yoluyla sadakat oluşturma üzerine üniversite mezunları arasında yapılan bir çalışma. Cumhuriyet Üniversitesi iiBF Dergisi, 9(1), 81-110.

Cooper, H. M. (1979). Statistically combining Independent studies: A meta-analysis of sex differences in conformity research. Journal of Personality and Social Psychology, 37(1), 131-146.

Çelik, M., \& Turunç, Ö. (2010). Lider desteğinin çalışanların iş-aile yaşam çatışması ve iş performansına etkisi: Savunma sektöründe bir araştırma. Çukurova Üniversitesi iiBF Dergisi, 14(1), 19-41.

Çokluk, Ö., Şekercioğlu, G., \& Büyüköztürk, Ş. (2010). Sosyal bilimler için çok değişkenli istatistik: SPSS ve LISREL uygulamaları. Ankara: Pegem Akademi.

Demirbağ O., Bilginoğlu E., \& Yozgat, U. (2013). Kariyer basamaklarında yükselirken geribildirim arayışında örgütün öğrenme transferine verdiği destek, yönetici desteği ve psikolojik güven algısının rolü. 21 Ulusal Yönetim ve Organizasyon Kongresi Bildiriler Kitabı, 64-69.

Demirel, Y. (2008). Örgütsel güvenin örgütsel bağlılık üzerine etkisi: Tekstil sektörü çalışanlarına yönelik bir araştırma. Celal Bayar Üniversitesi Yönetim ve Ekonomi Dergisi, 5(2), 179-194.

Demirkasımoğlu, N. (2012). Kamu ve özel ilköğretim okulu sınıf öğretmenlerinin psikolojik sözleşme algıları ve iş çevresine uyum düzeyleri ile ilişkisi. Ankara Üniversitesi Eğitim Bilimleri Enstitüsü, Yayımlanmamış Doktora Tezi, Ankara.

Dilek, H., \& Bilgin, N. (2012). Lider desteği ve sosyal desteğin iş performansına etkisinde özdeşleşmenin rolü: Konaklama sektöründe bir uygulama. 20. Ulusal Yönetim ve Organizasyon Kongresi Bildiri Kitabı, Dokuz Eylül Üniversitesi, İzmir: Kardeşler Kitabevi, 183-189.

Doğan, H. Z. (1987). Insan davranışları ve insan ilişkileri. İzmir: Uğur Ofset Matbaacılık ve Ticaret.

Dökmen, Ü. (2004). Küçük şeyler. İstanbul: Sistem Yayıncılık.

Eagly, A. H., \& Chrvala, C. (1986). Sex differences in conformity: Status and gender role interpretations, Psychology of Women Quarterly, 10(3), 203-220.

Eagly, A. H., Wood, W., \& Fishbaugh, L. (1981). Sex differences in conformity: Surveillance by the group as a determinant of male nonconformity. Journal of Personality and Social Psychology, 40(2), 384-394.

Eisenberger, R., Fasolo P., \& Lamastro, V. D. (1990). Perceived organizational support and employee diligence, commitment, and Innovation. Journal of Applied Psychology, 75(1), 51-59.

Eisenberger, R., Huntington R., Hutchison, S., \& Sowa, D. (1986). Perceived organizational support. Journal of Applied Psychology, 71(3), 500-507.

Eisenberger, R., Stinglhamber, F., Vandenberghe, C., Sucharski, I. L., \& Rhoades, L. (2002). Perceived supervisor support: Contributions to perceived organizational support and employee retention. Journal of Applied Psychology, 87(3), 565-573.

Emhan, A. (2012). Relationship among managerial support, job satisfaction and organizational commitment: A comparative study of nonprofit, for-profit and public sectors in Turkey, International Journal of Business, Humanities and Technology, 2(5), 179-190.

Emhan, A., Kula, S., \& Tongur, A. (2013). Yapısal eşitlik modeli kullanarak yönetici desteği, örgütsel bağlılık, örgütsel performans ve tükenmişlik kavramları arasındaki ilişkilerin analizi: Kamu sektöründe bir uygulama. H.Ü. Iktisadi ve Idari Bilimler Fakültesi Dergisi, 31(1), 53-69.

Erdoğdu, M. Y., \& Aydındağ, Z. (2013). Öğretmenlerin kurumsal özdeşleşme ve bağlılıklarının algılanan yönetici davranışları açısından incelenmesi. İstanbul Zaim Üniversitesi Sosyal Bilimler Dergisi, 158-172.

Erkuş, A. (2011). Çok boyutlu lider-izleyici etkileşiminde kişilik özelliklerinin ve güç kaynaklarının rolü. Atatürk Üniversitesi İktisadi ve Idari Bilimler Dergisi, 25(1), 127-152.

Freedman, J. L., Sears, D. O., \& Carlsmith, J. M. (2003). Introduction to social psychology (4. Baskı). Çev. Ali Dönmez, Sosyal psikoloji. Ankara: İmge Kitabevi.

Gagnon, M. A., \& Michael, J. H. (2004).Outcomes of supervisor support for wood production employees. Forest Products Journal, 54, 172-177.

Göktepe, E. A. (2016). Yeni kariyer tutumları, algılanan yönetici desteği ve işe tutkunluk arasındaki ilişki: Bir araştırma. İstanbul Üniversitesi Sosyal Bilimler Enstitüsü, Yayımlanmamış Doktora Tezi, İstanbul.

Grandey, A. A. (1999). The effects of emotiional labor: Employee attitudes, stress and performance. Colorado State Universtity, Yayınlanmış Doktora Tezi, Colorado. 
Grandey, A. A. (2000). Emotion regulation in the workplace: A new way to conceptualize emotional labor. Journal of Ocupational Health Psychology, 5(1), 95-110.

Gülova, A. A., Palamutçuoğlu, B. T., \& Palamutçuoğlu, A. T. (2013). Duygusal emek ile işe bağlılık arasındaki ilişkide amir desteğinin rolü: Üniversitede öğrenci işleri personeline yönelik bir araştırma. Dokuz Eylül Üniversitesi Iktisadi ve idari Bilimler Fakültesi Dergisi, 28(2),41-74.

Hogg, M. A., \& Vaughan, G. M. (2011). Sosyal psikoloji (2. Baskı) (Çev. İ. Yıldız ve A. Gelmez). Ankara: Ütopya Yayınları.

Hortaçsu, N. (2012). En güzel psikoloji sosyal psikoloji. Ankara: İmge Kitabevi.

Ilerler, T. (2017). Örgüt kültürü ile çalışanların kurallara uyma davranışı arasındaki ilişkide yönetici desteğinin rolü: Havacılık sektöründe bir araştırma. Manisa Celal Bayar Üniversitesi Sosyal Bilimler EnstitüsüYayımlanmamış Doktora Tezi, Manisa.

Kağıtçıbaşı, Ç. (1988). Insan ve insanlar (7. Baskı). İstanbul: Evrim Yayınevi.

Kağıtçıbaşı, Ç. (2010). Günümüzde insan ve insanlar sosyal psikolojiye giriş (12. Baskı). İstanbul: Evrim Yayınevi.

Kağıtçıbaşı, Ç. (2013). Günümüzde insan ve insanlar sosyal psikolojiye giriş (14. Baskı). İstanbul: Evrim Yayınevi.

Kalaycı, Ş. (2010). SPSS uygulamalı çok değişkenli istatistik teknikleri. Ankara: Asil Yayın Dağıtım.

Kaya, Ç., \& Altınkurt, Y. (2018). Öğretmenlerin psikolojik sermayeleri ile tükenmişlik düzeyleri arasındaki ilişkide psikolojik ve yapısal güçlendirmenin rolü. Eğitim ve Bilim Dergisi, 43(193), 63-78.

Kaya, M., Güneş G., Kaya B., \& Pehlivan, E. (2004). Tıp fakültesi öğrencilerinde boyun eğici davranışlar ve şiddetle ilişkisi. Anadolu Psikiyatri Dergisi, (5), 5-10.

Kelman, H. C. (1958). Compliance, identification and internalization: Three processes of attitude change. Journal of Conflict Resolution, 2(1), 51-60.

Kılıçlar, A., \& Harbalığolu, M. (2014). Örgütsel sessizlik ve örgütsel vatandaşlık davranışı arasındaki ilişki: Antalya'daki beş yıldızlı otel işletmeleri üzerine bir araştırma. İşletme Araştırmaları Dergisi, 6(1), 328-346.

Koç, M., Bayraktar B., \& Çolak, S. (2010). Üniversite öğrencilerinde boyun eğici davranışlarının çeşitli değişkenler açısından incelenmesi. Erciyes Üniversitesi SBÜ Dergisi, 28(1), 257-280.

Kopp, L. R. (2013). The effects of perceived supervisor work-life support on employee work- life balance, job satisfaction, organizational commitment, and organizational citizenship behavior. Master of Science in Applied Psychology Degree, http://www2.uwstout.edu/content/lib/thesis/2013/2013koppl.pdf (Erişim Tarihi: 01.08.2014).

Kossek, E., Pichler, S., Bodner, T., \& Hammer, L. B. (2011). Workplace social support and work-family conflict: A metaanalysis clarifying the influence of general and work-family-specific supervisor and organizational support. Personnel Psychology, 64(2), 289-313.

Kottke, J. L., \& Sharafinski, C. E. (1988). Measuring perceived supervisory and organizational support. Educational and Psychological Measurement, 48(14), 1075-1079.

Maertz, C. P., Griffeth, R. W., Campbell, N. S., \& Allen, D. G. (2007). The effects of perceived organizational support and perceived supervisor support on employee turnover. Journal of Organizational Behavior, 28(8), 1059-1075.

Meydan, C. H., \& Şeşen, H. (2015). Yapısal eşitlik modellemesi ve Amos uygulamaları (2. Baskı), Ankara: Detay Yayıncılık.

Muse, L. A., \& Pichler, S. A. (2011). Comparison of types of support for lower-skilled workers: Evidence for the importance of family supportive supervisors. Journal of Vocational Behavior, 79(3), 653-666.

Newman, A., Thanacoody R., \& Hui, W. (2011). The effects of perceived organizational support, perceived supervisor support and intra-organizational network resources on turnover intentions: A study of Chinese employees in multinational enterprises. Personnel Review, 41(1), 56-72.

O'reılly, C. A., \& Chatman, J. (1986). Organizational commitment and psychological attachment: The effectsof compliance, Identification, and Internalization on prosocial behavior. Journal of Applied Psychology, 71(3), 492499.

Öz, E. Ü. (2007). Duygusal emek davranışlarının çalışanların iş sonuçlarına etkisi. İstanbul: Beta Basım Yayın Dağıtım.

Özalp, i. (1992). Işletmelerde yönetim ve organizasyon. Eskişehir: Beytaş Yayıncılık.

Özdemir, A. (2010). İlköğretim okullarında algılanan yönetici desteğinin ve bireycilik-ortaklaşa davranışçılığın örgütsel vatandaşlık davranışı ile ilişkisi. Kuram ve Uygulamada Eğitim Yönetimi Dergisi, 16(1), 93-112.

Özdevecioğlu, M. (2003). Algılanan örgütsel destek ile örgütsel bağlılık arasındaki ilişkilerin belirlenmesine yönelik bir araştırma. Dokuz Eylül Üniversitesi i.i.B.F. Dergisi, 18(2), 113-130. 
Polat, M., \& Meydan, C. H. (2010). Örgütsel özdeşleşmenin sinizm ve işten ayrılma niyeti ile ilişkisi üzerine bir araştırma. Savunma Bilimleri Dergisi, 9(1), 145-172.

Rahim, M. A. (1989). Relationships of leader power to compliance and satisfaction with supervision: Evidence from a national sample of managers. Journal of Management, 15(4), 545-556.

Rhoades, L., \& Eisenberger, R. (2002). Perceived organizational support: A review of the literatur. Journal of Applied Psychology, 87(4), 698-714

SGHM (2016). Faaliyet Raporu. http://web.shgm.gov.tr/documents/sivilhavacilik/files/pdf/kurumsal/faaliyet/2016.pdf

Singh, J. (2000). Performance productivity and quality of frontline employees in service organizations. Journal of Marketing, 64, 15-34.

Sümer, N. (2000). Yapısal eşitlik modelleri: Temel kavramlar ve örnek uygulamalar. Türk Psikoloji Yazıları, 3(6), 49-74.

Şıkel, P. (2011). Müşterilerin internet bankacılığını benimsemelerine yönelik keşifsel bir araştırma. Niğde Üniversitesi internet Uygulamaları ve Yönetimi Dergisi (IUYD), 2(2), 35-50.

Şimşek, G. (2002). Kitle iletişim formu olarak reklamcılık. Selçuk Üniversitesi Iletişim Fakültesi Akademi Dergisi, 2(2), 5663.

Şimşek, Ş. (2005). Yönetim ve organizasyon (8. Baskı). Konya: Seçkin Dağıtım.

Tak, B., \& Çiftçioğlu, A. (2009). Algılanan örgütsel prestij ile örgütsel bağlılık ve örgütsel özdeşleşme arasındaki ilişkilerin incelenmesine yönelik bir araştırma. Akdeniz Üniversitesi i.i.B.F. Dergisi, 18, 100-116.

Tokgöz, E., \& Seymen, O. A. (2013). Örgütsel güven, örgütsel özdeşleşme ve örgütsel vatandaşlık davranışı arasındaki ilişki: Bir devlet hastanesinde araştırma. Marmara Üniversitesi Öneri Dergisi, 39(10), 61-76.

Tongur, A. (2011). Organizational support, organizational citizenship behavior, and perceived performance in crime scene Investigation units of Turkish National Police. Unpublished Dissertation, Orlando.

Turunç, Ö. (2011). Örgütsel adaletin çalışanların örgütsel özdeşleşme ve işten ayrılma niyetine etkisi: Örgütsel özdeşleşmenin aracılık rolü. İş-Güç Endüstri ilişskileri ve Insan Kaynakları Dergisi, 13(1), 145-168.

Türkay, O., Ünal A., \& Taşar, O. (2011). Motivasyonel ve yapısal etkenler altında duygusal emeğin işe bağlılığa etkisi. ZKÜ Sosyal Bilimler Dergisi, 7(14), 201-222.

Tüzün, i. K., \& Çağlar, ì. (2008). Örgütsel özdeşleşme kavramı ve iletişim etkinliği ilişkisi. Yaşar Üniversitesi Dergisi, 3(9), 1011-1027.

Usluel, Y. K., Avcı Ü., Kurtoğlu, M., \& Uslu, N. (2013). Yeniliklerin benimsenmesi sürecinde rol oynayan değişkenlerin betimsel tarama yöntemiyle incelenmesi. Pamukkale Üniversitesi Eğitim Fakültesi Dergisi, 1, 53-71.

Usta, S. T., \& Eyüpoğlu, K. (2010). Bireysel internet bankacılığını benimsemesini etkileyen faktörlerin yapısal eşitlik modeli ile belirlenmesi. BDDK Bankacılık ve Finansal Piyasalar, 4(2), 11-38.

Uzun, T. (2018). Okullarda algılanan örgütsel adalet, yönetici desteği ve örgütsel özdeşleşme arasındaki ilişki. Trakya Eğitim Dergisi, 8(4), 776-789.

Üçkardeş, í. (2012). Risk analizi ve havacılık sektöründe kaza risklerinin değerlendirilmesi. Çukurova Üniversitesi Fen Bilimleri Enstitüsü, Yüksek Lisans Tezi, Adana.

Vries, K. D., Manfred, F. R., \& Miller, D. (1986). Personality, culture and organizations. Academy of Management Review, 11(2), 266-279.

Yaşar, M. F., Emhan, N. A., \& Ebere, P. (2014). Analysis of organizational justice, supervisor support, and organizational commitment: A case study of energy sector in Nigeria. Journal of Business Studies Quarterly, 5(3), 37-46.

Yener, M., \& Aykol, S.E. (2009). Girişimcilik değerleri ve örgütsel vatandaşlık davranışı üzerine bir araştırma. Süleyman Demirel Üniversitesi IiBF Dergisi, 14(1), 255-271.

Yoon, J., \& Lim, J. (1999). Organizational support in the workplace: The case of Korean hospital employees. Human Relations, 52(7), 923-945.

Yüksel, Ö., \& Aykaç, B. (1994). Frederick Taylor'ın görüşlerinin değerlendirilmesinde yeni bir yaklaşım. Amme idaresi Dergisi, 27(4), 83-96.

Zimbardo, P. G., \& Leippe, M. R. (1991). The psychology of attitude change and social influence. USA: Graw- Hill. 
This Page Intentionally Left Blank 